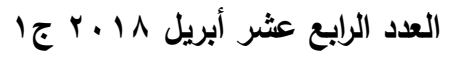

\section{التسويق المبسي في ظل الثورة المصرية}

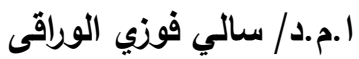 \\ قسم الملابس والنسيج - كلية الاقتصاد المنزلى - جامعة المنوفية

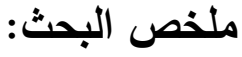

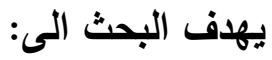

1 - التعرف على الفرق بين التسويق الملبسي قبل وبعد الثثرة بالنسبة لأصحاب المصانع والتجار .

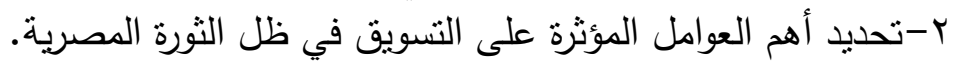

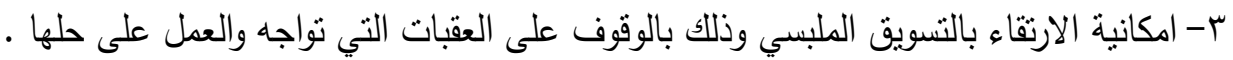

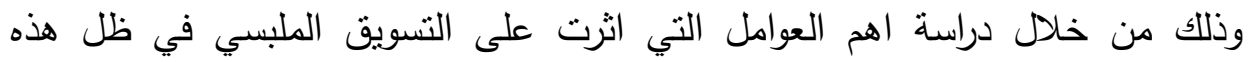

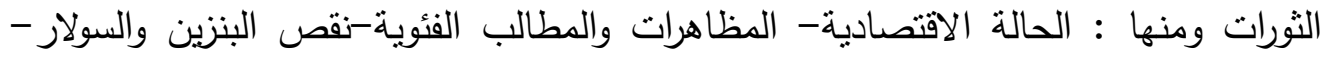

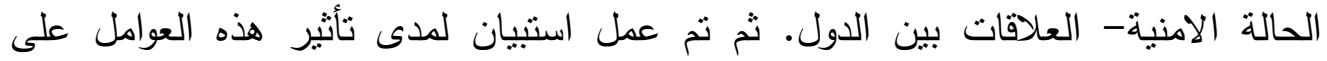

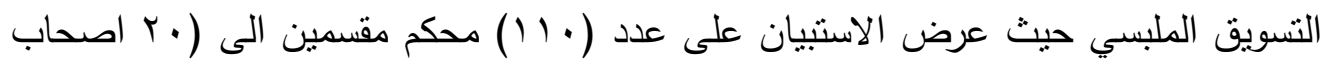
مصانع) و (9 تجار ) و تم عمل الدراسة الاحصائية لنتائج الاستبيان.

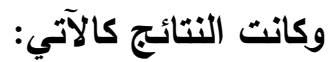

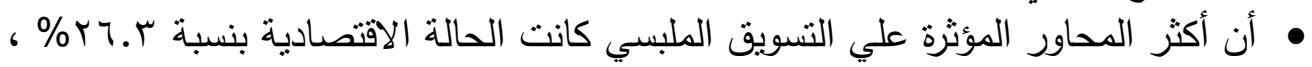

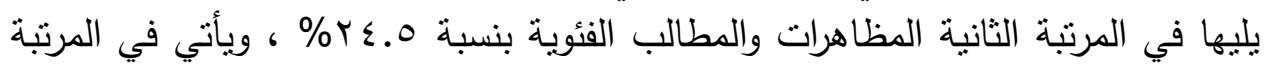

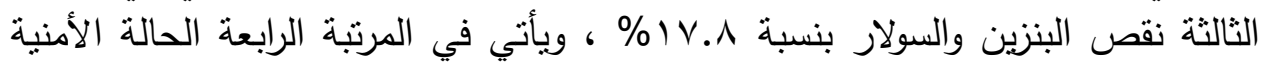

\section{Summary}

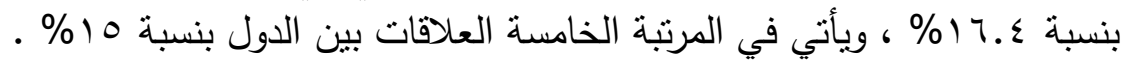

The research aims to:

1- Identify the difference between marketing clothing before and after the revolution for the owners of factories and traders.

2 - Determining the most important factors affecting marketing in light of the Egyptian revolution.

3 - the possibility of upgrading the clothing marketing by standing on the obstacles that face and work to solve them.

This is done by studying the most important factors that affected the marketing of clothes under these revolutions, including: economic situation, demonstrations and class demands, shortage of petrol and diesel, security situation, and relations between countries. A survey was conducted on the effect of these factors on the marketing of clothing. The questionnaire was presented to (110) arbitrators divided into (20 factory owners) and (90 traders).

The results were as follows:

- The most important axes affecting clothing marketing were the economic situation with $26.3 \%$, followed by demonstrations and class demands by $24.5 \%$, gasoline and diesel shortages by $17.8 \%$ and security by $16.4 \%$ Fifth relations among countries by $15 \%$. 


\section{المقدمة والمشكلة البحثية:}

لقد مرت البلاد بالعديد من الثورات والتي لها من آثار عديدة في شتى المجالات وبالاخص في المجال الملبسي

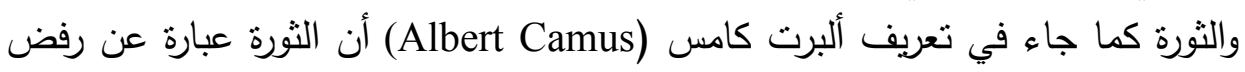

الوضع القائم فهي تحرك السلوك السياسي وهي فعل اختبار ورفض من خلال عمل عنيف.

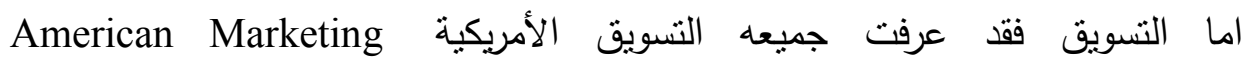
Association ، التسويق بأنه" أداء أنشطة الأعمال التي تعني بتدفق السلع والخدمات من

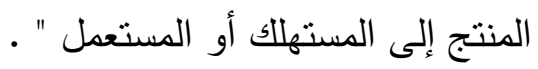

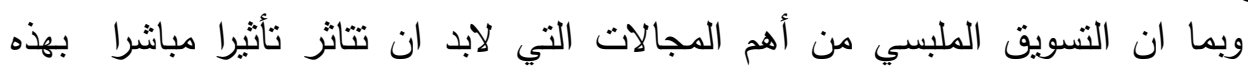

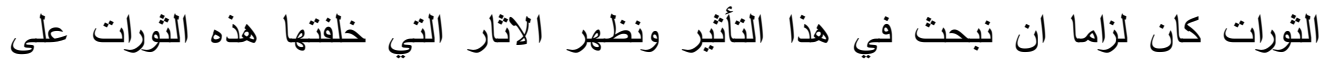

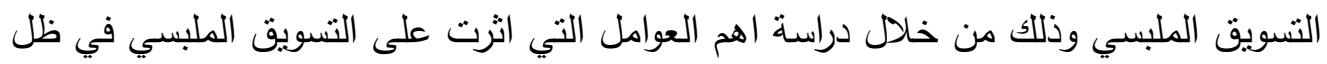

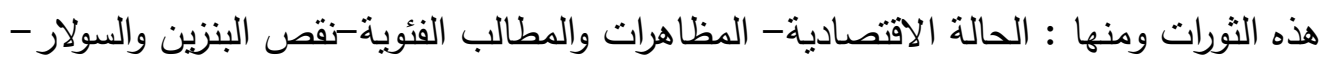

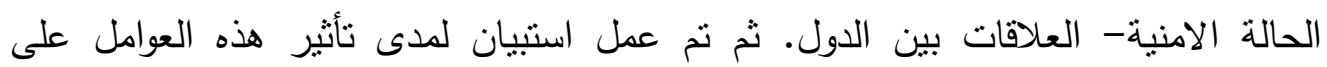

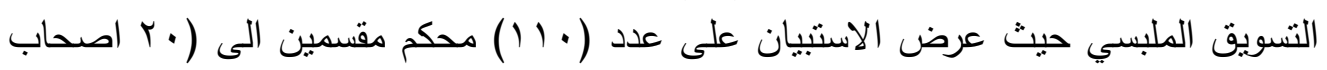

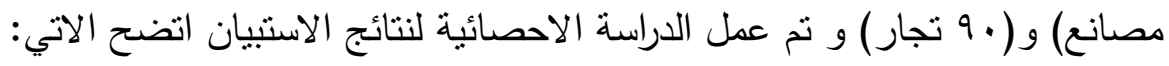

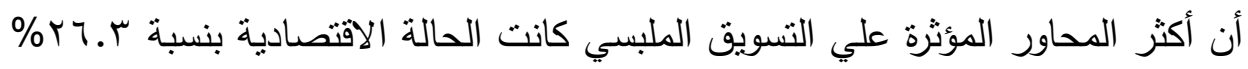

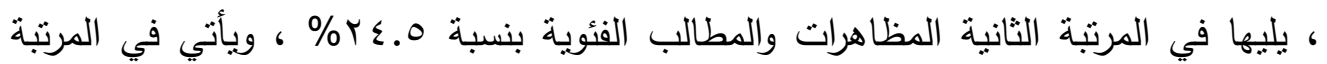

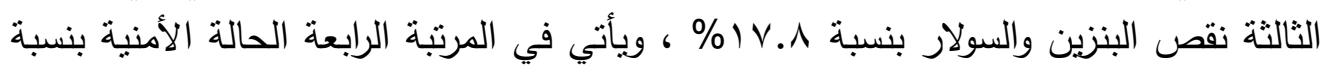

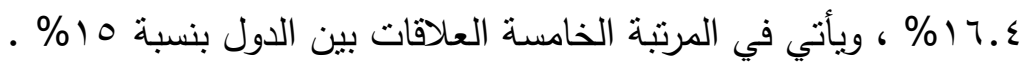
ومن الدراسات السابقة التي تناولت التسويق الملبسي:

Malgorzata Koszewska "Understanding Consumer Behavior in the Sustainable Clothing Market: Model Development and Verification”- -2015 هذف هذه الدراسة هو نوسيع معرفة سلوك المستهلك في السوق من أجل الملابس

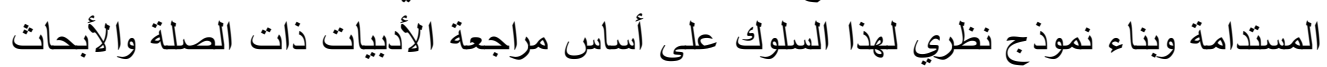

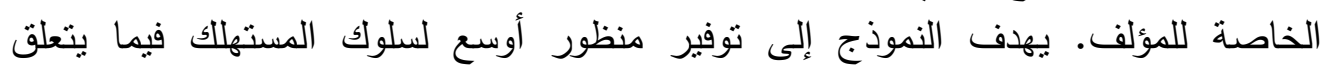

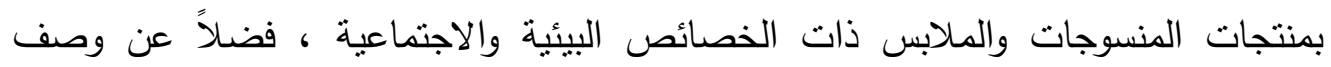
العلاقة بين المستهلك والثركة المصنعة للمنسوجات والملابس التي تنتع استراتيجية (المسؤولية التئية

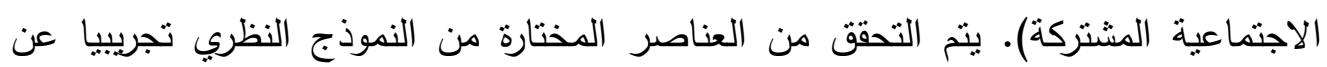

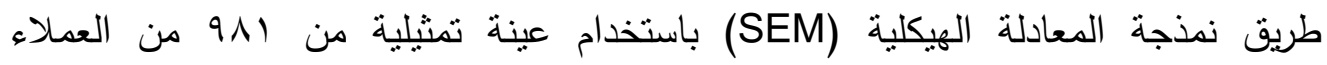

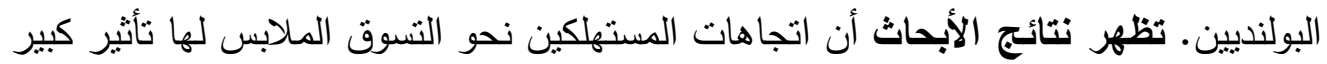

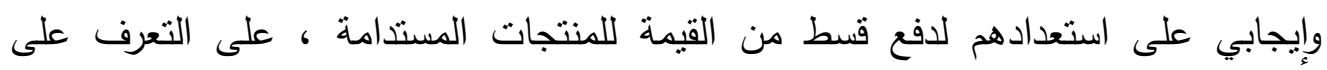
العلامات البيئية والاجتماعية ، وأخيرا ، على الثراء الفعلي للملابس المستدامة. هذه النتائج 
تعطي أدلة إضافية نتير إلى دور بارز في التعرف على العلامات البيئية والاجتماعية في

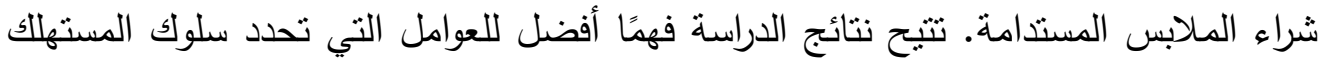
تجاه الملابس المستدامة واقتراح حلول عملية لمنتجيها.

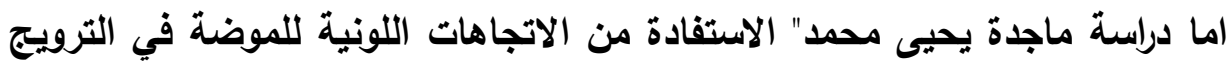

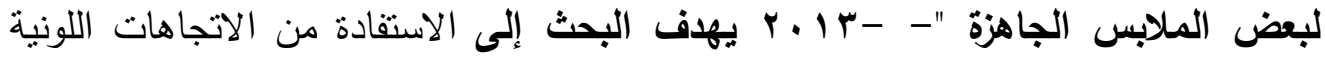

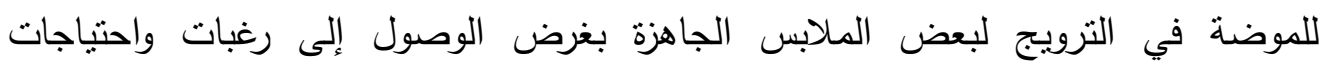

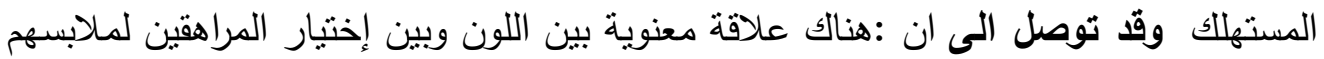

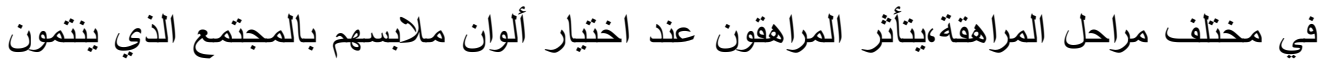

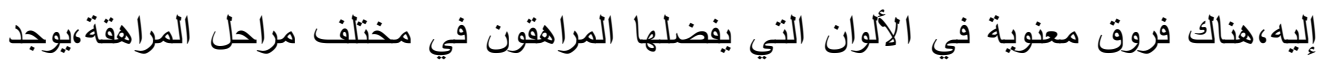

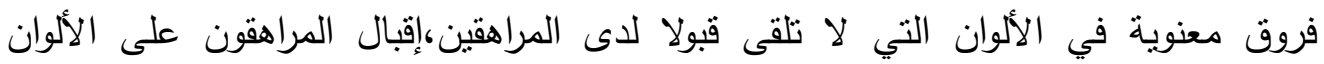

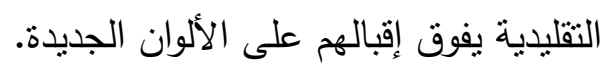

Koszewska M " Social and eco-labelling of textile and clothing goods as means of communication and product differentiatio2011"-

\section{وكان الهُف من هذا إلى البحث إلقاء الضوء على الثهادات ووضع البطاقات "}

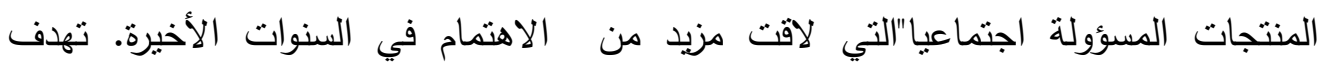

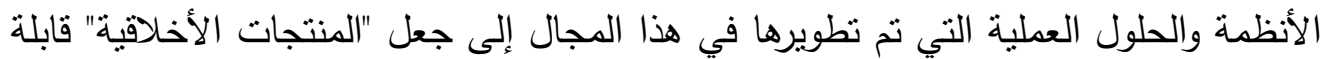

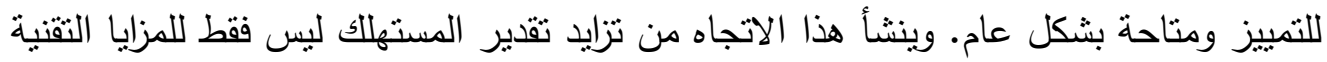

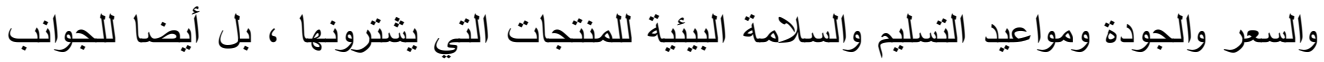

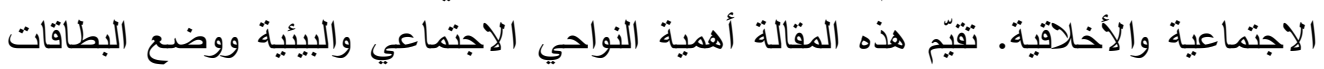

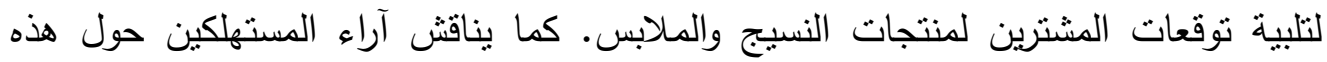

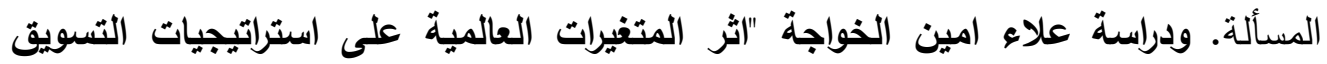

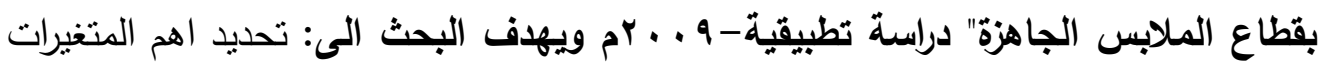

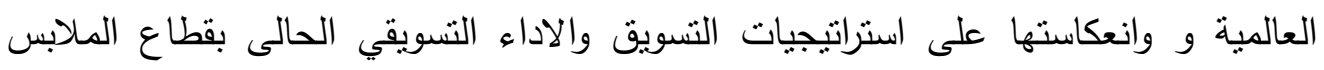

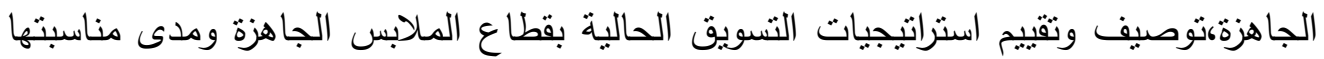

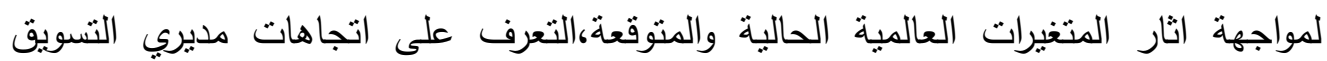

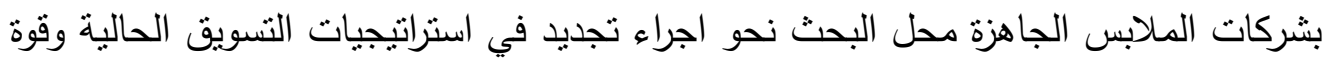

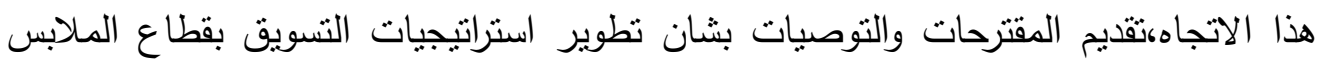

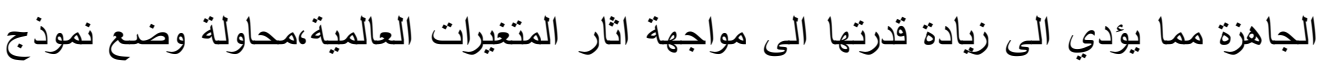

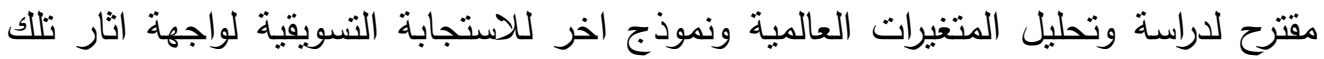

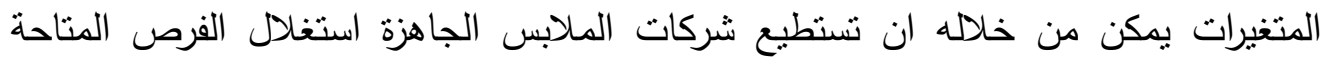

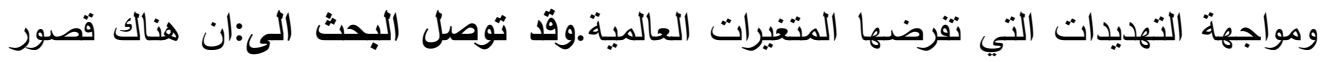

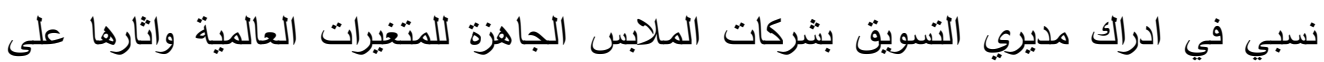


استراتيجيات التسويق،هناك تأثير قوي ذات دلالة معنوية للمتغيرات العالمية على الاستراتيجيات

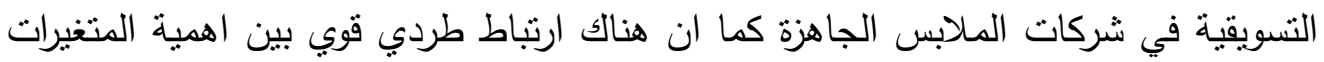

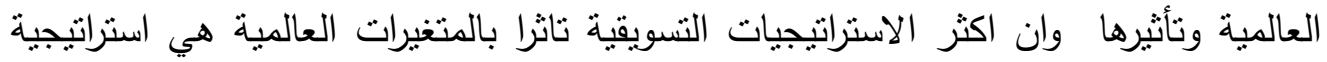

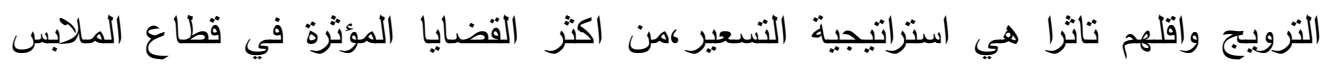

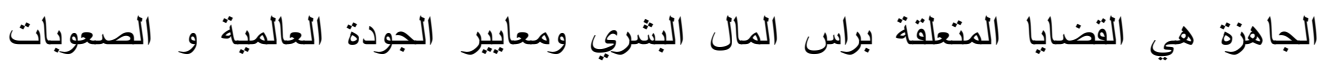

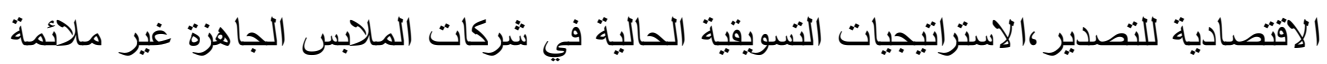

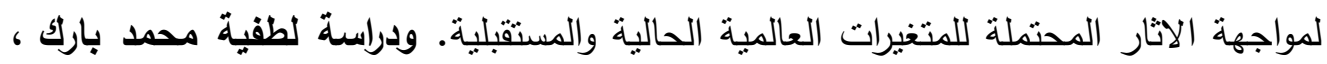
داليا عبد الكريم قنديل" دراسة بعض المشاكل التهات التسويقية للملابس الجاهزة النسائية المصنعة

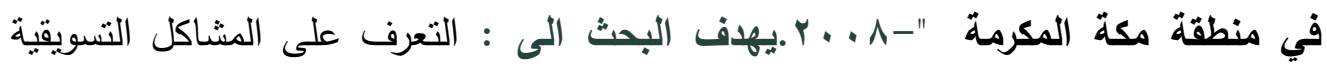

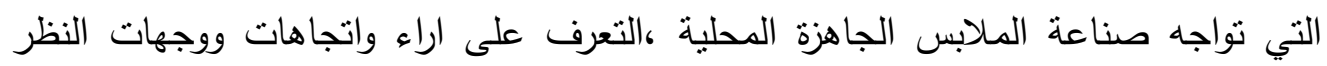

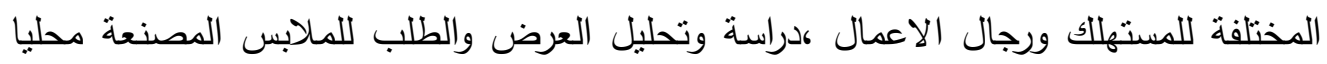

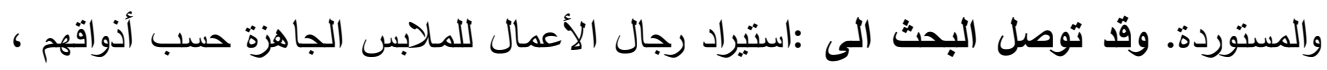

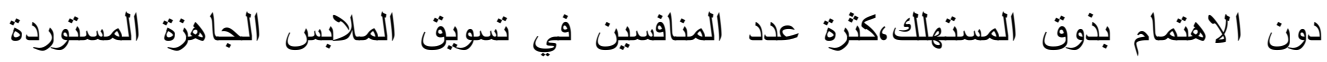

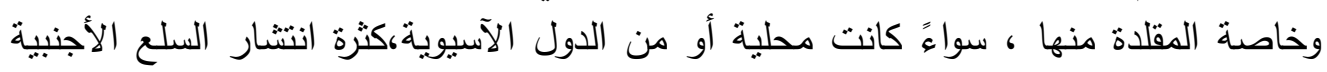

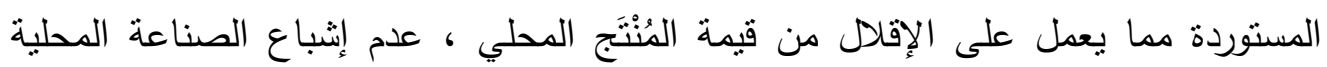

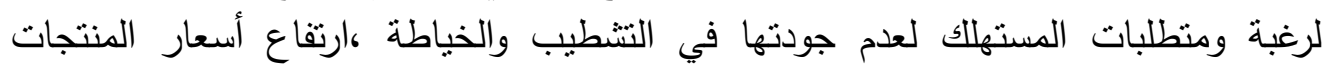

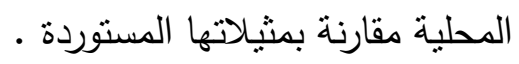

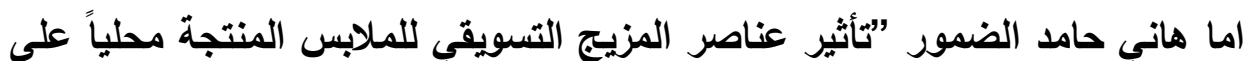

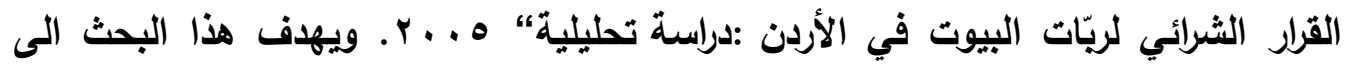

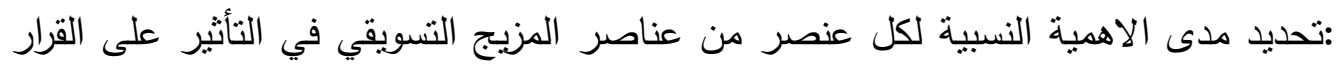

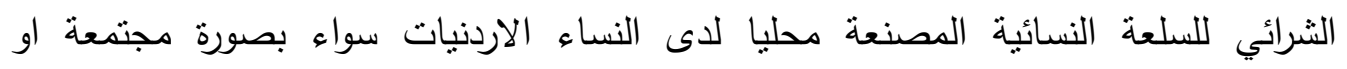

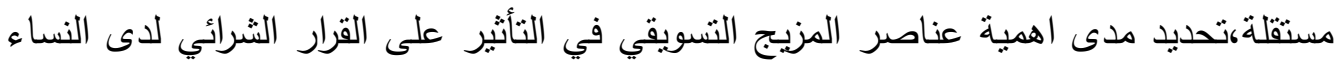

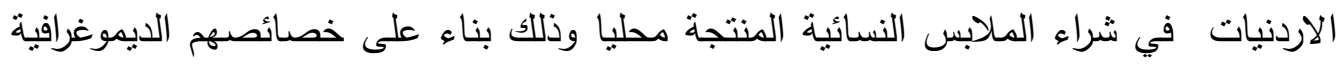

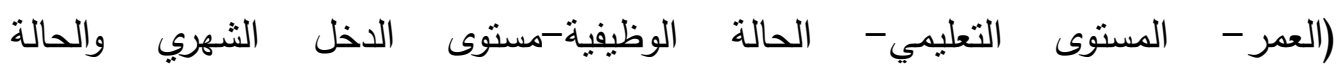

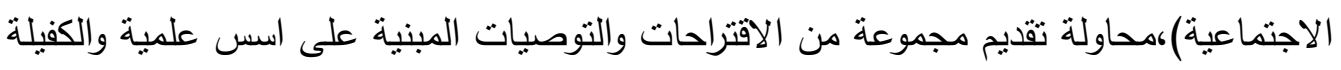

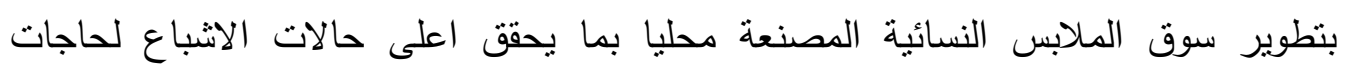
المستهلكين والتي تتصف بالتغيير السريع .وقد توصل البحث الى :وجود اختلاف لدى النئ النساء

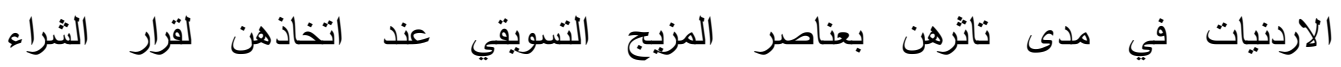

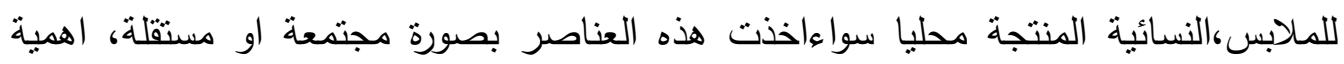

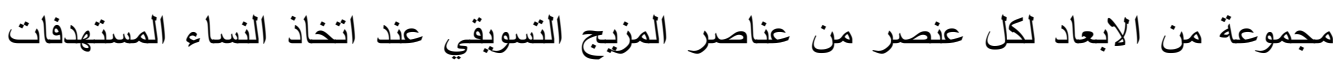

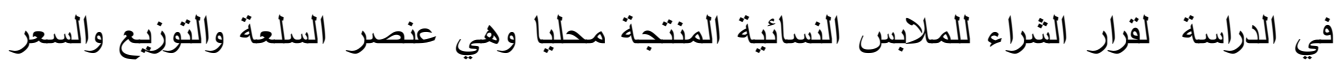

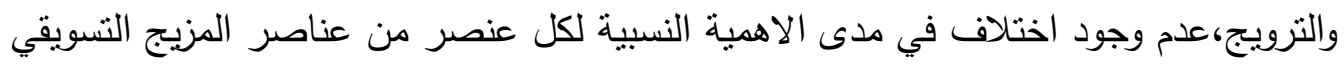


عند اتخاذ النساء المستهدفات في الدراسة لقرار الثراء للملابس النسائية المنتجة محليا

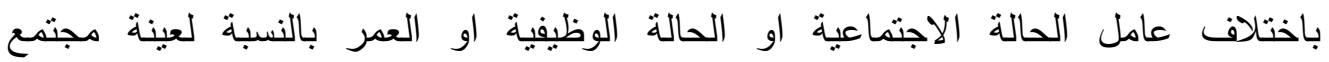

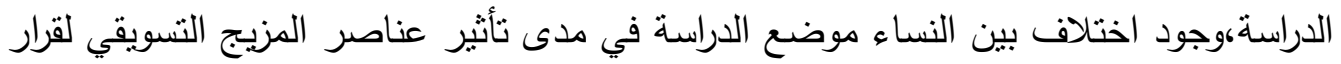
الشراء للملابس النسائية المنتجة محليا باختلاف مستوى تعليمهن ومستوى دخلهلن. الما منال يوسف نجيب " علاقة التصميم بالتسويق لأقمشة الملابس المطبوعة للأطفال"-ء ـ. . ؟.

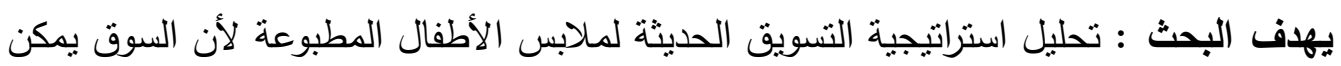

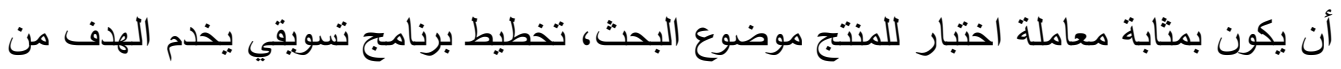

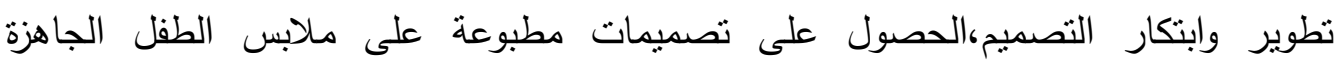

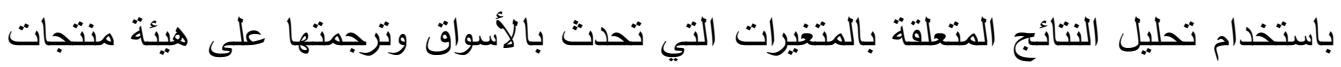

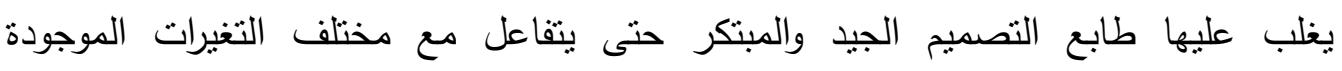

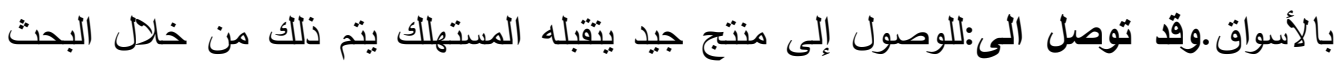

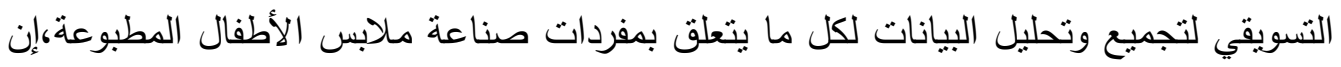

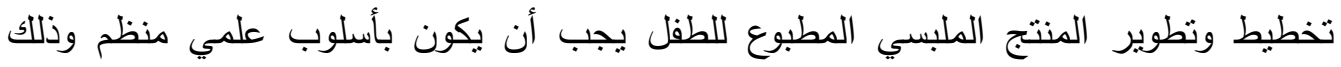

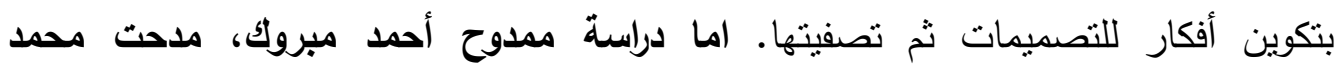

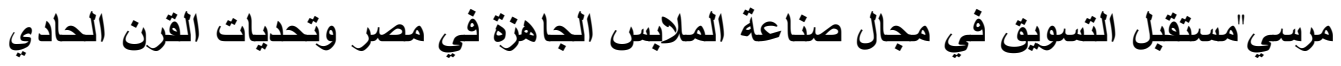

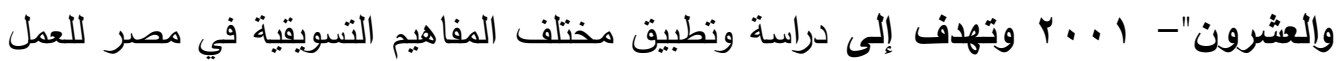

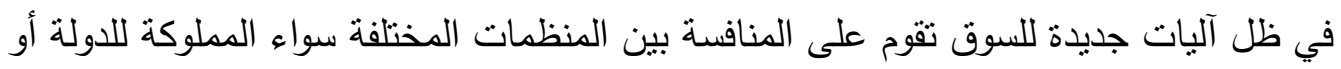

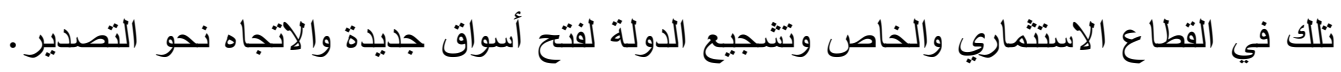

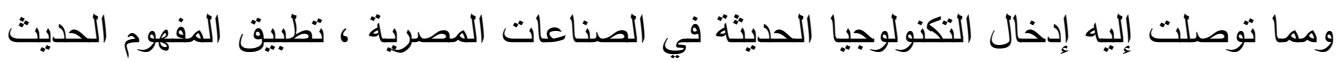

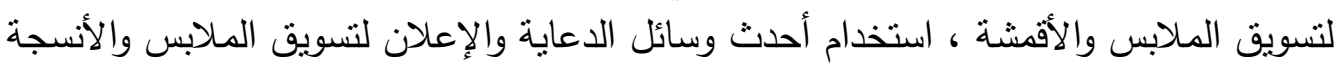

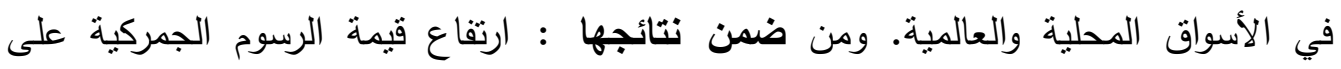

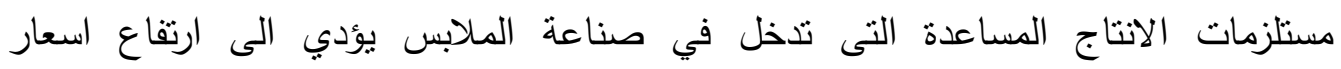

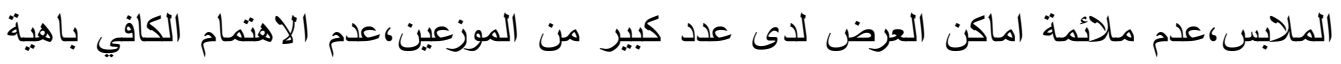

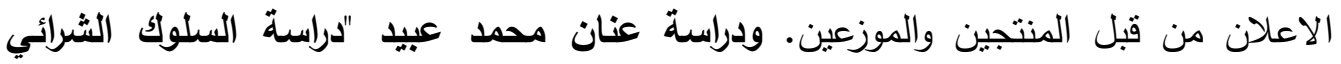

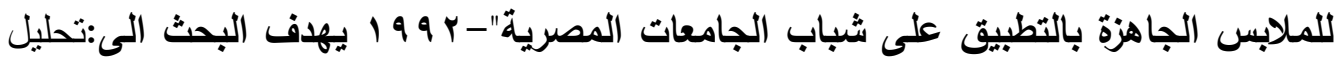

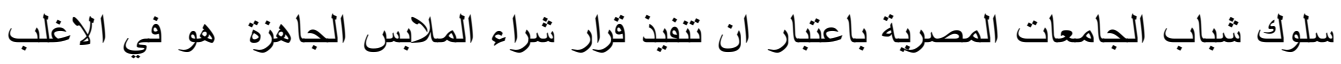

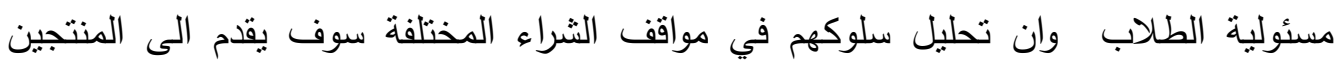

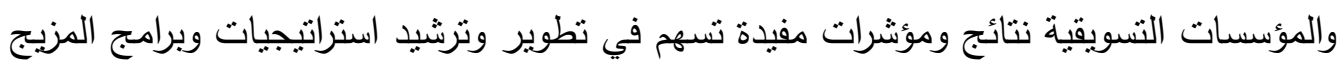
التسويقي الذي يتوجهون بع الى الاسواق المستهدفة.

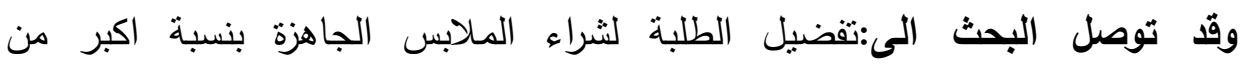

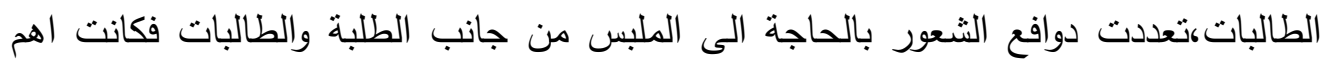
الدوافع بالنسبة للطلبة بدء الفصول والمناسبات وللطالبات رؤية ملابس الاخرين،يهتم الطلبة 
عند الثراء اكثر بالماركة ثم اسم وشهرة المتجر بينما يتجه اهتمام الطالبات اولالاسم وشهرة

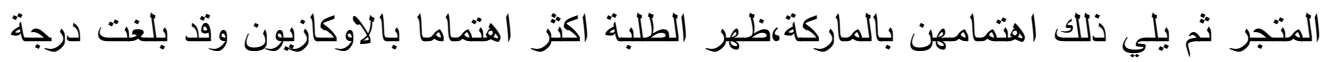

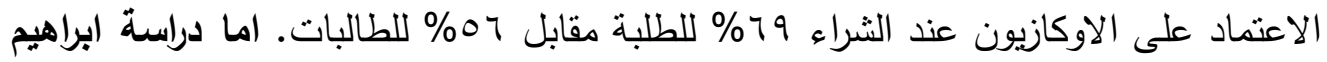

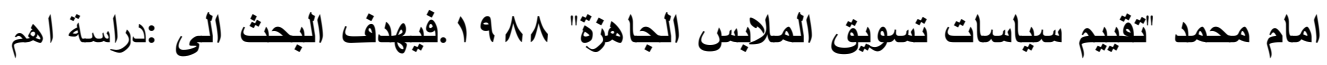

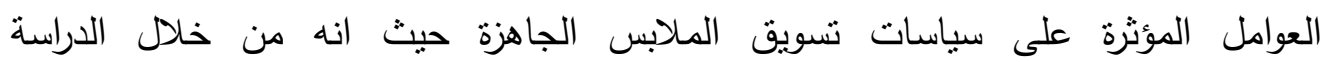

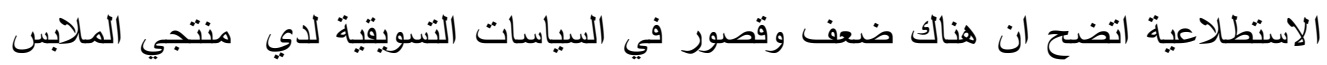

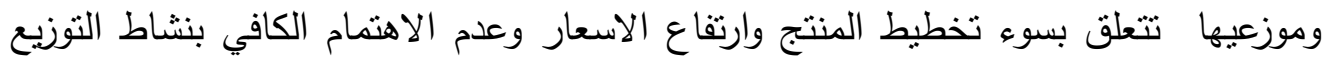

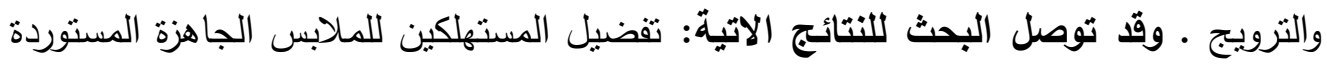

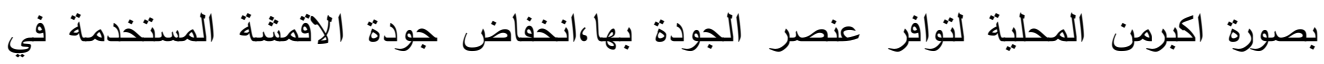
صناعة الملابس الجاهزة،ضعف الدراسات التي اجريت في سبيل وضع مقاست مقاسات مناسبة

للمستهكين،عدم وجود العمالة المتدربة الكافية نتج عنه كثرة العيوب في تشطبيات الملابس الجاهزة . التعليق على الاراسات السابقة: نجد ان الدراسات السابقة فد تعرضت للسلوك الملبسي والعوامل التي تؤثر عليه وطرق

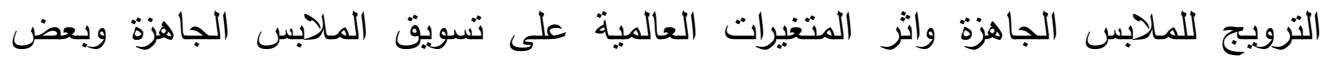

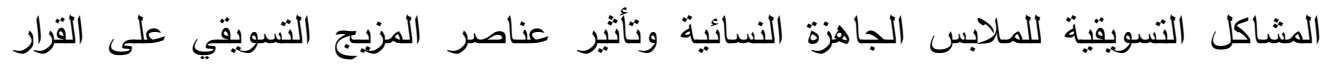

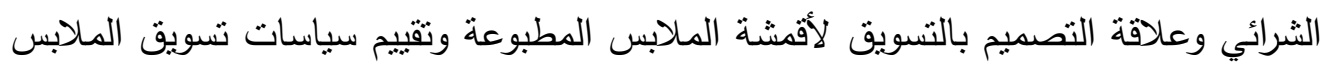

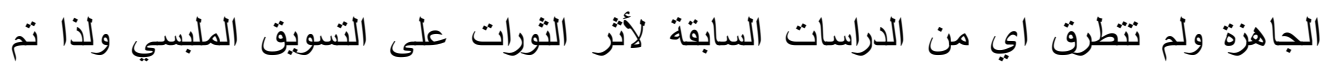

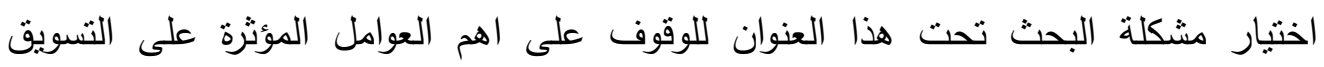

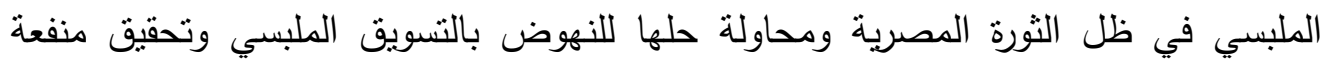
اقتصادية في هذا المجال. وقد استفادت الارسية من الداراسات الدابن السابقة في:

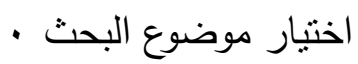

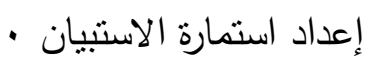
مشكلة البحث: تتلخص مشكلة البحث في الرد على التساؤلات الآتية:

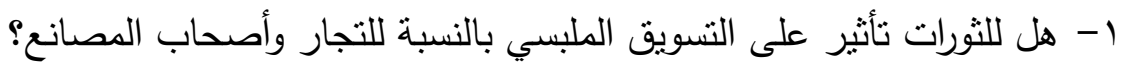

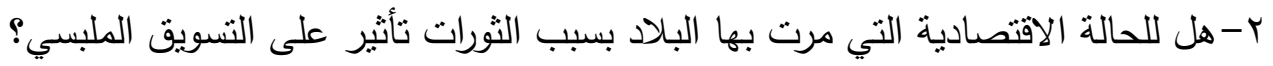

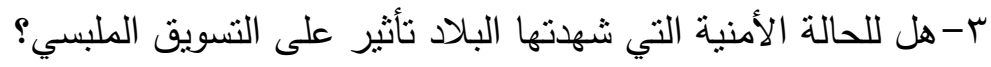

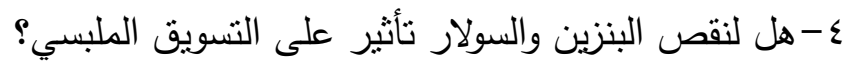

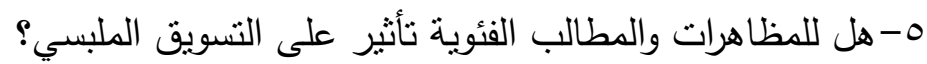

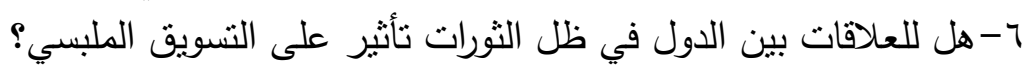


1-توجد فروق ذات دلالة إحصائية بين متوسط درجات أفراد العينة في التسويق الملبسي قبل

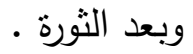

r-توجد فروق ذات دلالة إحصائية بين متوسط درجات أصحاب المصانع والتجار في تأثنير

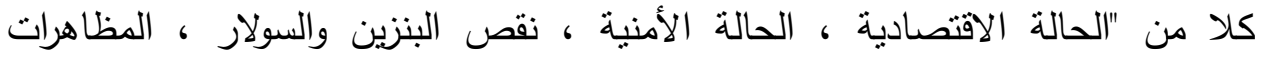

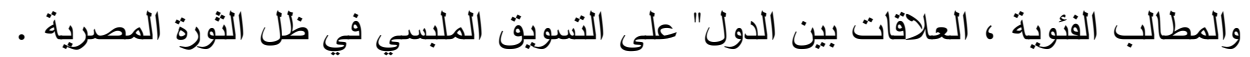

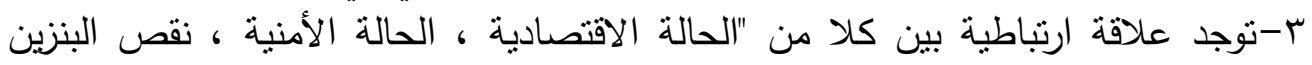

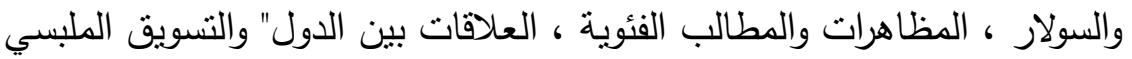

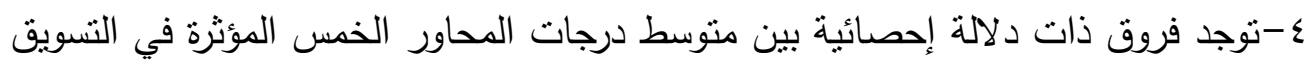

الملبسي وفقا لأراء أفراد العينة

$$
\text { هيدف هذا البحث: }
$$

1 - التعرف على الفرق بين التسويق الملبسي قبل وبعد الثثرة بالنسبة لأصحاب المصانع والتجار . r-تحديد اهم العوامل المؤثرة على التسويق في ظل الثون الثورة المصرية.

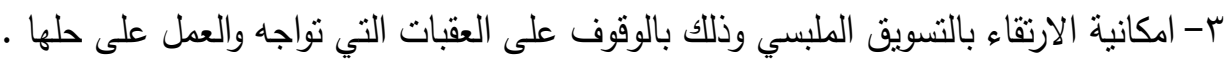

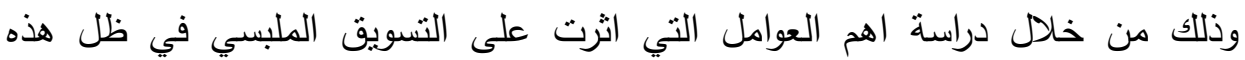

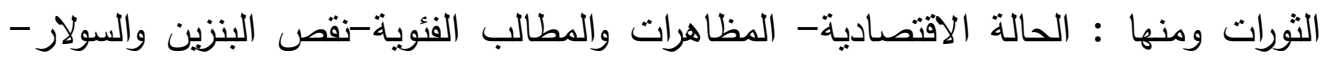

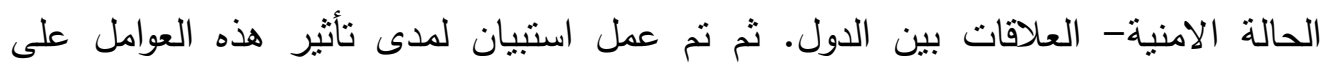

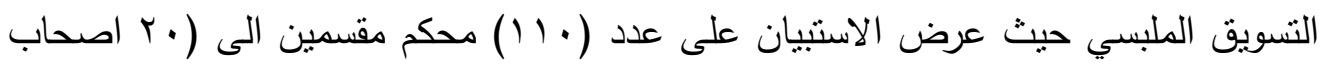
مصانع) و ( •9 تجار ) و تم عمل الدراسة الاحصائية لنتائج الاستنيان. أهمية البحث: وانمان

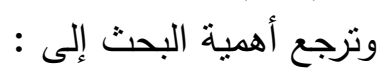

تعد هذه الدراسة الدراسة الاولى من نوعها والتي تهنت بمدى تاثر العملية التسويقية في

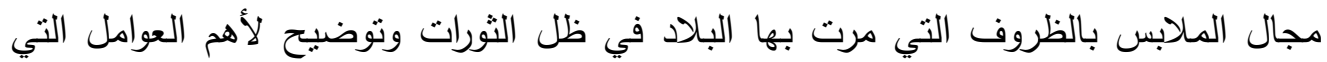

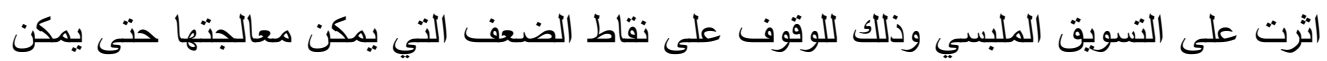
النهوض بتسويق الملابس الجاهزة.

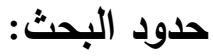

حدود مكانية: اجريت هذه الدراسة داخل جمهورية مصر العربية .

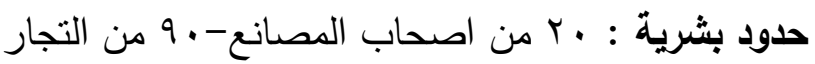
ادوات البحث:

استمارة استبيان لكل من اصحاب المصانع والتجار وقد تم جمع البيانات عن طريق

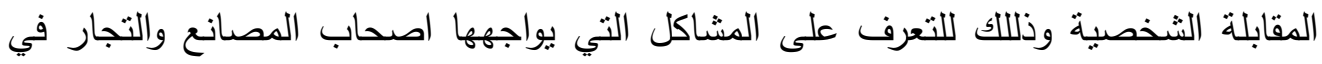
تسويق الملابس الجاهزة في ظل الثورات المصرية. 


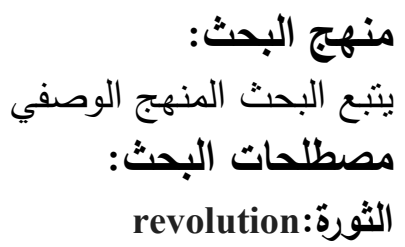

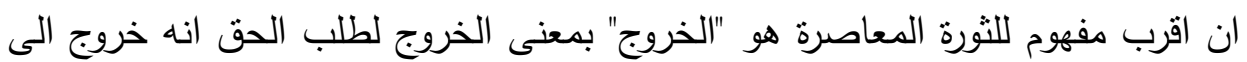

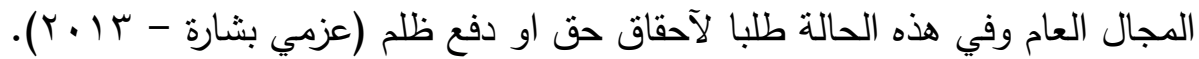

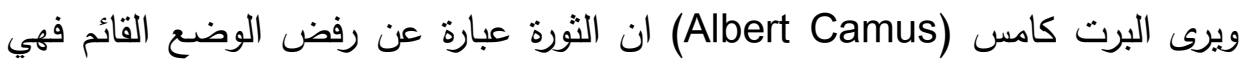
تحرك السلوك السياسي وهي فعل اختيار ورفض من خلال عمل عل عنديف.

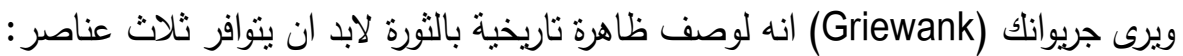

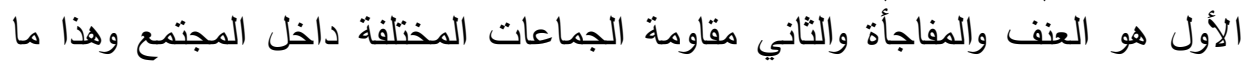

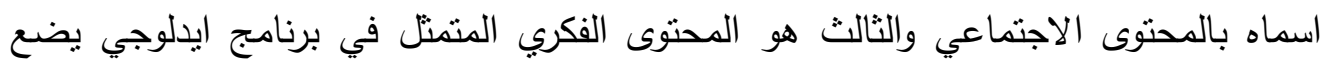

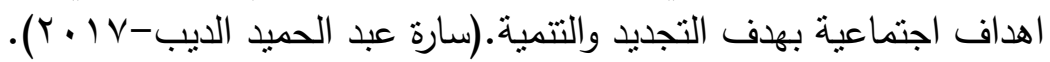

التسويق:Marketing

هو التعرف على حاجات الزبائن وارضائهر بشكل مريح، وله ثلاث الأن مكونات اساسية:

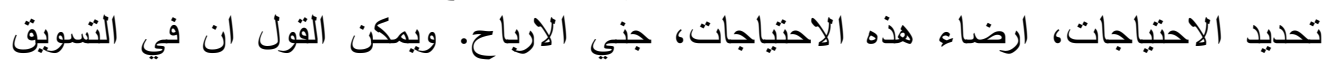

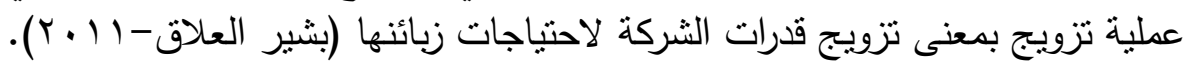

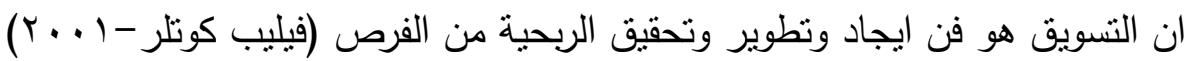

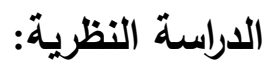

التسويق هو تحديد ما الذي سيتم بيعه ولمن سيتم البيع وشروط البيع ومنافذ التوزيع

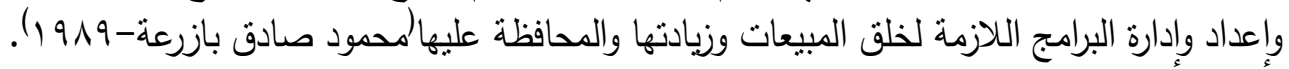

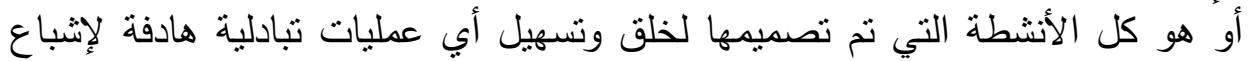

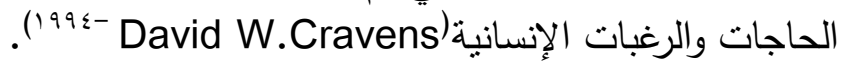
أو هو عبارة عن جميع أوجه النشاط التي تعمل على انتقال المنتجات من مراكز إنتاجها

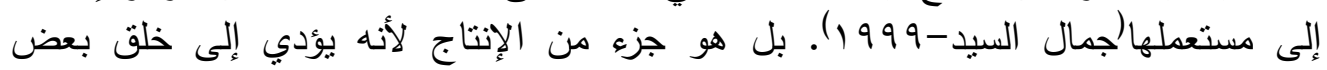

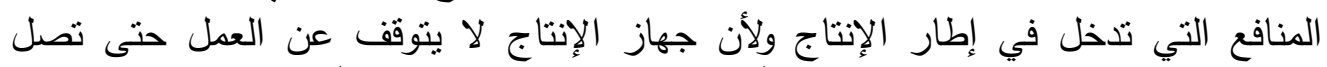

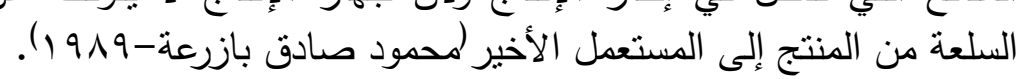

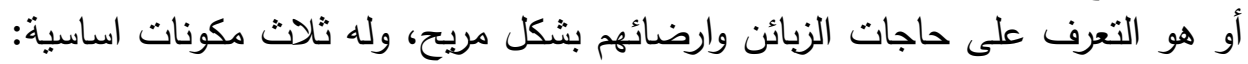

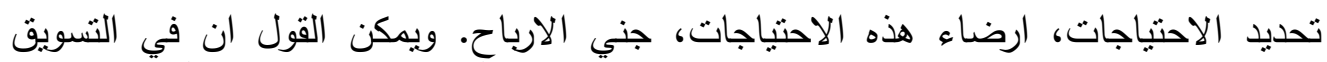

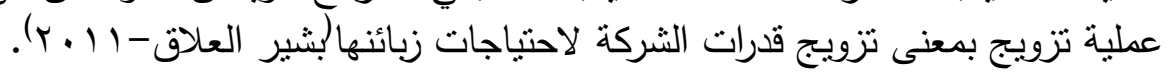

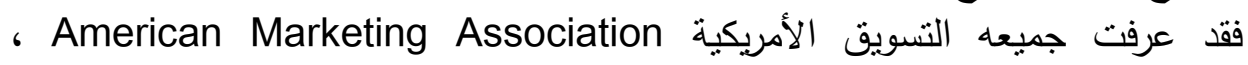

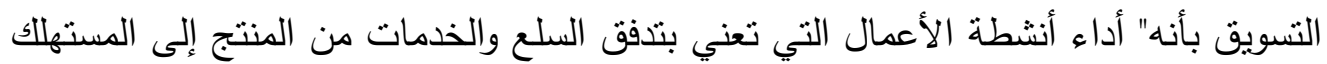

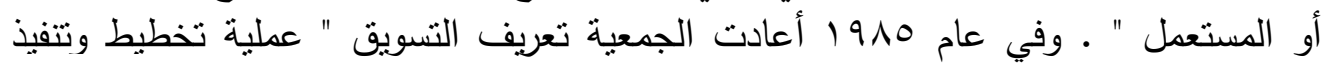

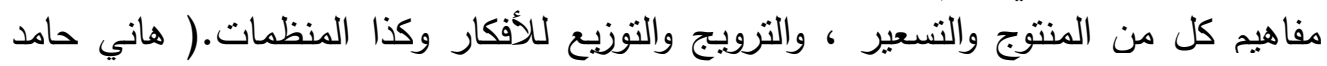

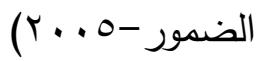




\section{سلوك المستهلك Consumer Behavior}

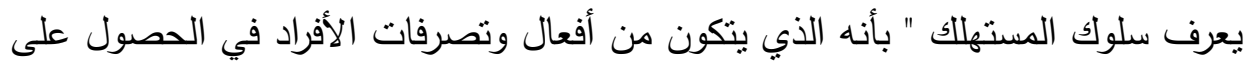

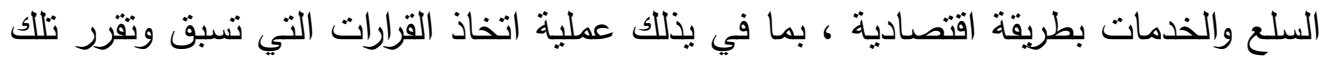

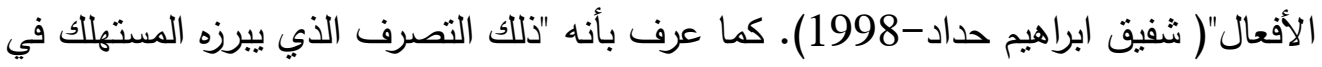

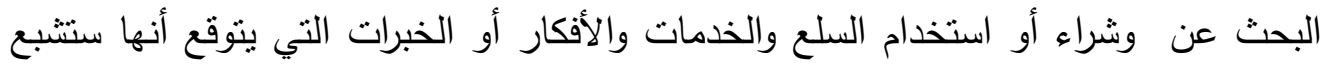

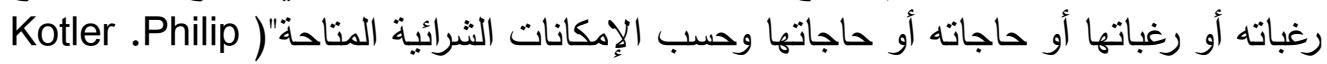
(and Keller-2006 إن عملية اتخاذ قرار المستهلك تؤكد على ترتيب معين للأحداث ( أو الخطوات) والتي : النيات

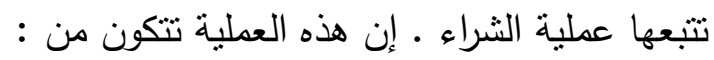

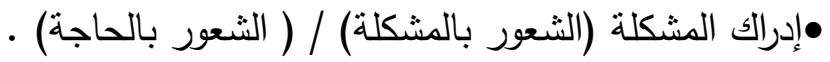
•البحث . •التقييم • بلثراء •تقييم ما بعد الشراء

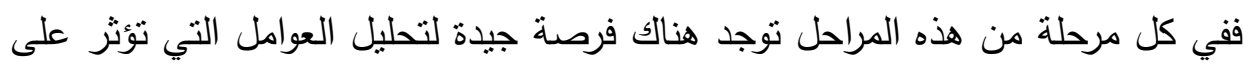

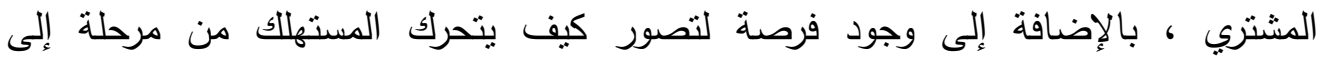
أخرى .( شفيق ابراهيم حداد-1998)

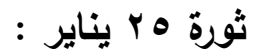

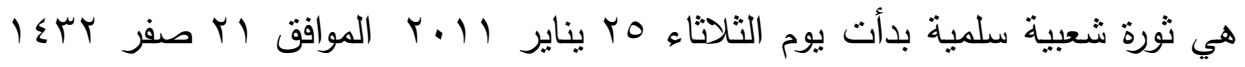

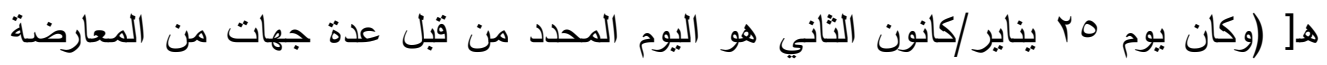

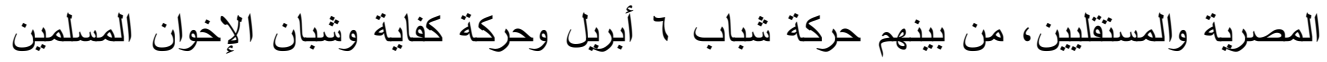

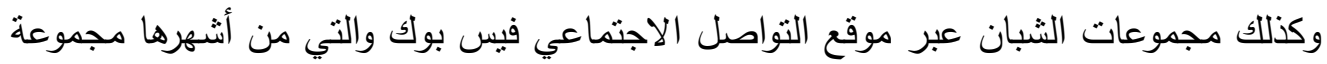

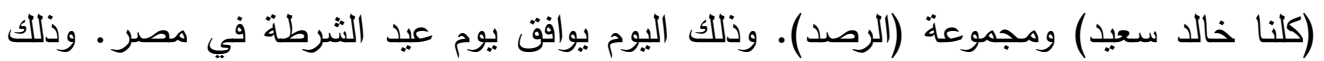

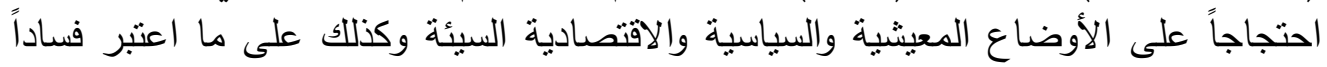

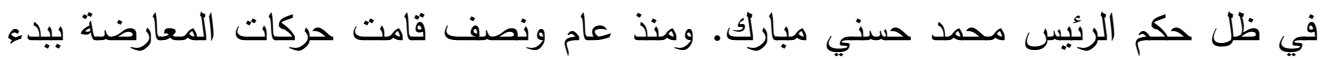

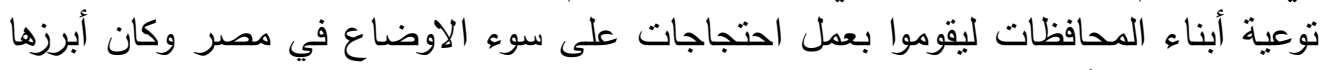

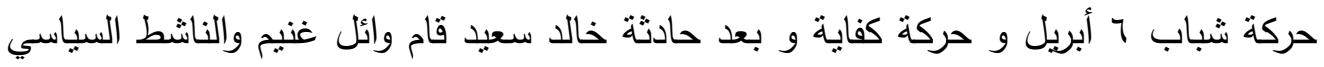

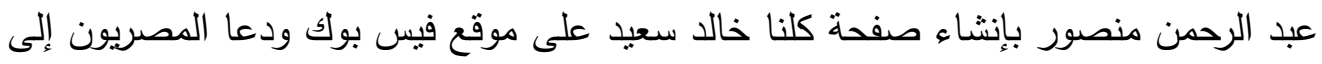

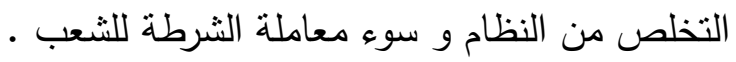

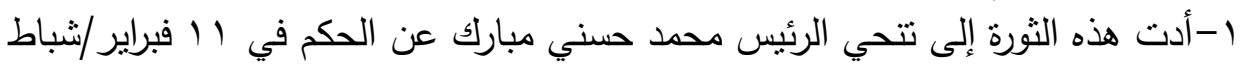

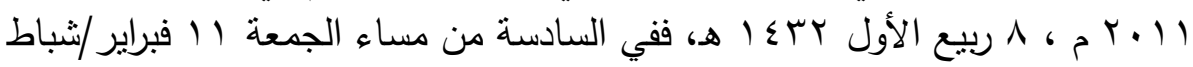

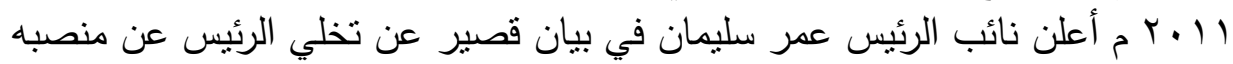

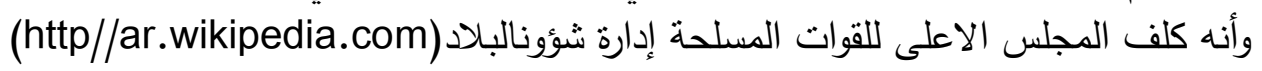




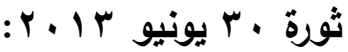

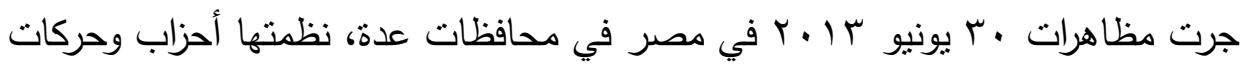

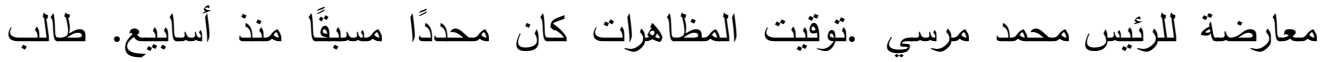

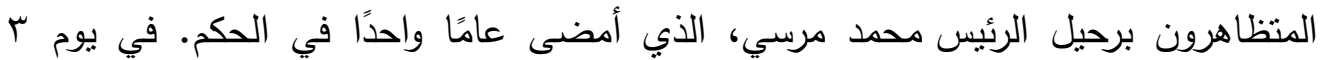

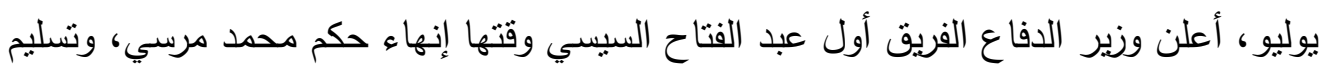

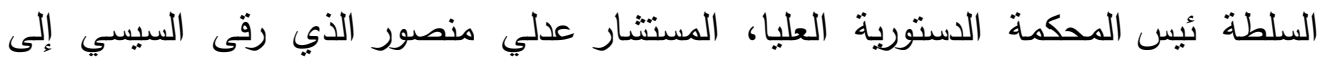

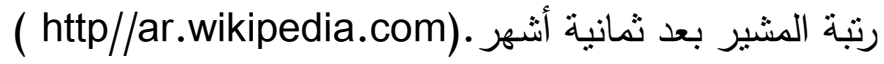

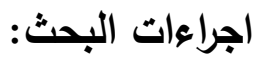

نم اختيار مجموعة من العوامل التى من المحتمل ان تكون اثرت على التسويق الملبسي في ظل الثورات المصرية. نم اعداد استبيان لمدى تأثثر هذه العوامل على التسويق الملبسي حيث عرض الماند الاستبيان

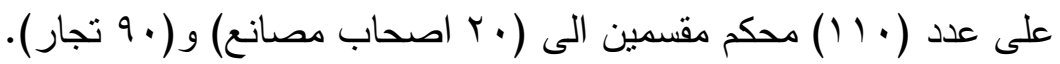

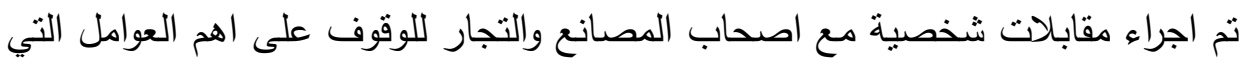
اثرت على التسويق الملبسي في ظل الثورة المصرية.

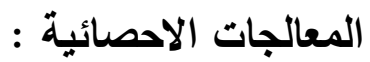
صدق وثبات للاستبيان

إختبار (ت) T-Test لمتوسط درجات أفراد العينة في التنسويق الملبسي قبل وبعد الثنورة.

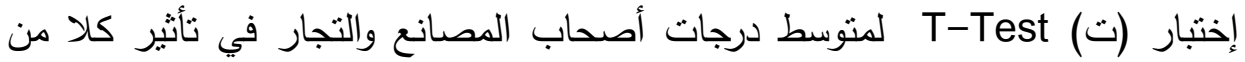

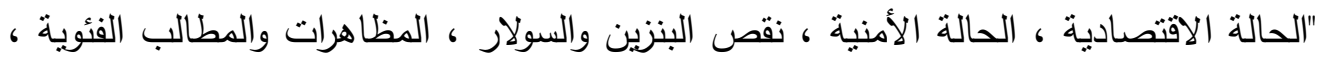

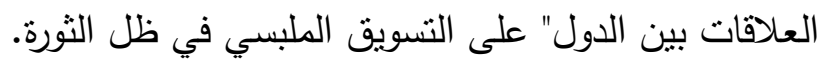

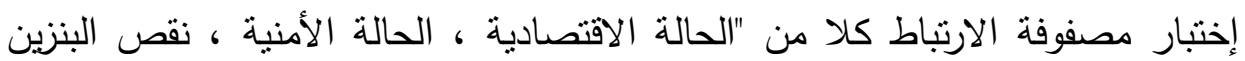
والسولار ، المظاهرات والمطالب الفئوية ، العلاقات بين الدول" والتسويق الملبسي.

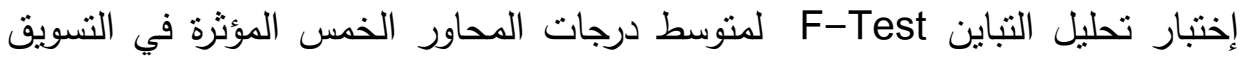
الملبسي وفقا لأراء أفراد العينة. إعداد جدول الوزن النسبي لأكثر المحاور المؤثرة علي التسويق الملبسي. الصدق والثبات

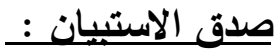
يقصد به قدرة الاستبيان على قياس ما وضع لقياسه . صدق الاتساق الاخلي : صلاخد حساب معاملات الارتباط بين الدرجة الكلية لكل محور من محاور الاستبيان والدرجة

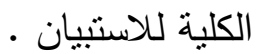


الصدق باستخدام الاتساق الداخلي بين الدرجة الكلبة لكل محور واللارجة الكلبة للاستبيان :

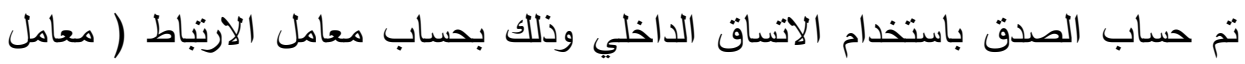

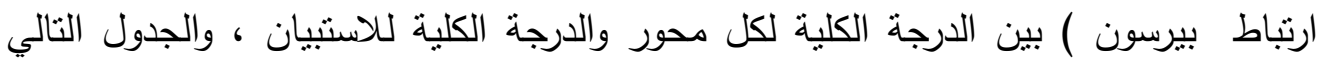
يوضح ذللك :

جدول ( 1 ) قيم معاملات الارتباط بين الدرجة الكلية لكل محور والدرجة الكلية للاستبيان

\begin{tabular}{|c|c|c|}
\hline 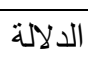 & الارتباط & 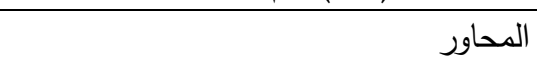 \\
\hline$\ldots 1$ &..$\vee 9$. & الدحور الأول : الحالة الاقتصادية \\
\hline$\ldots 1$ &. .170 & المحور الثاني : الحالة الأمنية \\
\hline$\ldots 1$ &..$v \varepsilon 1$ & المحور الثنالث : نقص البنزين والسولار \\
\hline$\ldots 1$ &. $.9 Y Y$ & المحور الرابع : الدظاهرات والمطالب الفئوية \\
\hline$\ldots 1$ & $\cdot . \wedge \cdot V$ & المحور الخامس : العلاقات بين الدول \\
\hline
\end{tabular}

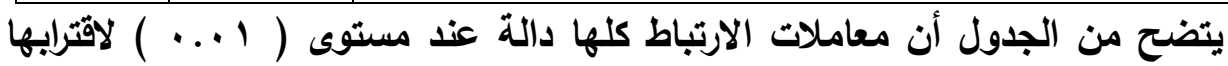
من الواحد الصحيح مما يدل على صدق وتجانس محاور الاستبيان . الثبات :

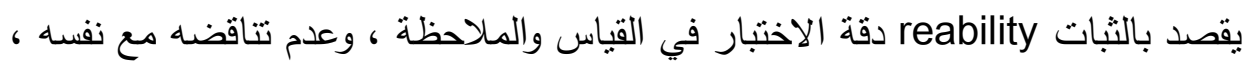

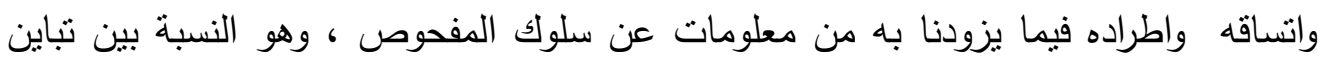

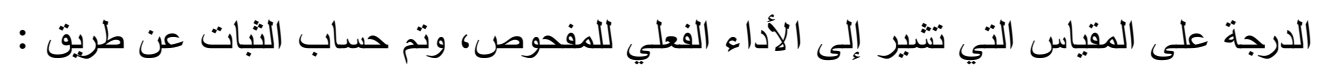

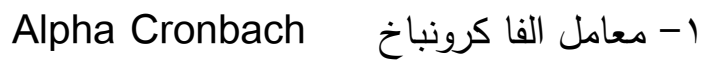

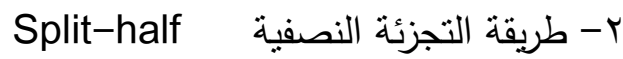
جدول ( ب ) قيم معامل الثبات لمحاور الاسنتيان

\begin{tabular}{|c|c|c|}
\hline |التجزئة النصفية & معامل الفا & 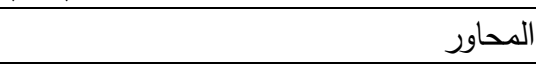 \\
\hline$\cdot . \wedge \cdot \Lambda-\cdot . V \mu 1$ &..$\vee \vee q$ & المحور الأول : الحالة الاقتصادية \\
\hline$\cdot .9 \varepsilon \cdot-\cdot . \wedge V Y$ &. $.91 \%$ & المحور الثاني : الحالة الأمنية \\
\hline$. .917-. .1 \leq 0$ &..$\wedge \wedge \mathrm{T}$ & الدحور الثالث : نقص البنزين والسولار \\
\hline$. V \wedge 0-. V 1 r$ &. .209 & الدحور الرابع : المظاهرات والدطالب الفئوية \\
\hline$. .941-. .170$ & $\cdot .9 \cdot 1$ & الدحور الخامس : العلاقات بين الدول \\
\hline$. .17 .-. .190$ &..$\wedge r V$ & ثبات الاستنيان ككل \\
\hline
\end{tabular}

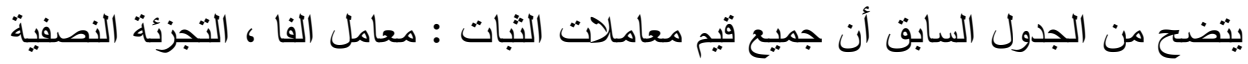

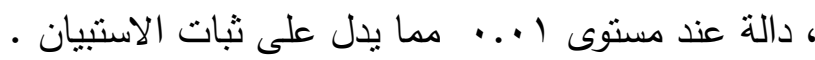

\section{النتائج الفرض الأول :}

نوجد فروق ذات دلالة إحصائية بين متوسط درجات أفراد العينة في التسويق الملبسي قبل وبعد الثورة 
وللتحقق من هذا الفرض نم تطبيق اختبار "ت" لمتوسط درجات أفراد العينة في التسويق

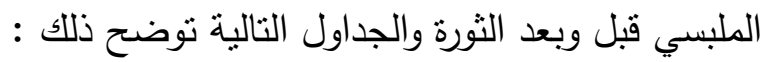
جدول ( r ) الفروق في متوسط درجات أفراد العينة في التسويق الملبسي قبل وبعد الثورة وفقا للحالة الاقتصادية

\begin{tabular}{|c|c|c|c|c|c|c|}
\hline الدلالة & قيمة (ت ) & الحرية & العينة & الانحراف & الحسابي & الحالة الاقتصادية \\
\hline \multirow{2}{*}{ لصالح قند الثل الثورة } & \multirow{2}{*}{ דיוניו } & \multirow{2}{*}{1.9} & \multirow{2}{*}{11.} & r.. ro & $19.0 Y 1$ & قبل الثورة \\
\hline & & & & 1.477 & II.YYV & بعد الثورة \\
\hline
\end{tabular}

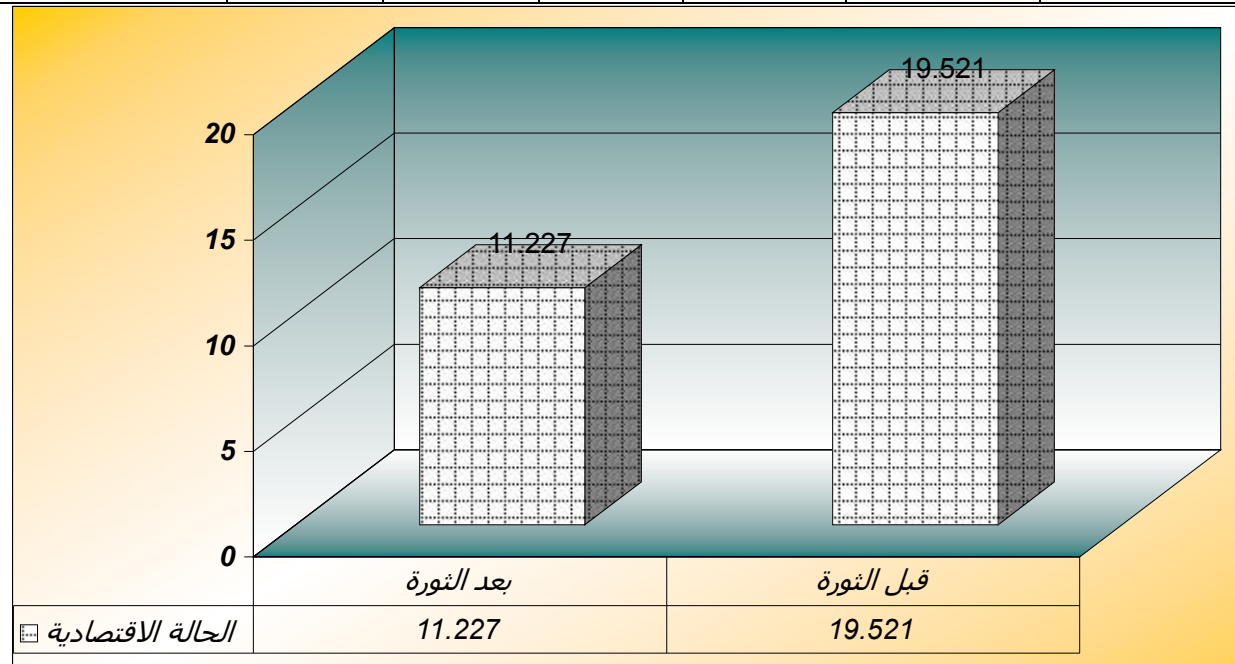

شكل ( 1 ) يوضح الفروق في متوسط درجات أفراد العينة في التسويق الملبسي قبل وبعد الثورة وفقا للحالة الاقتصادية أنادية في

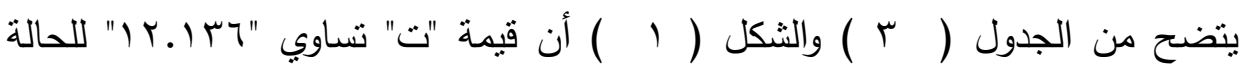

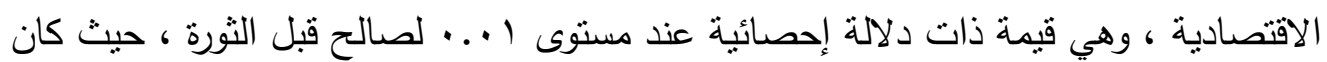

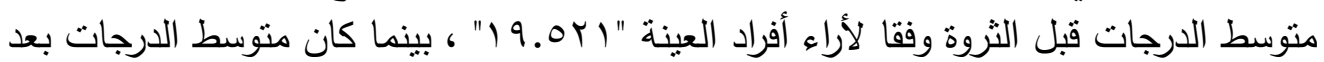

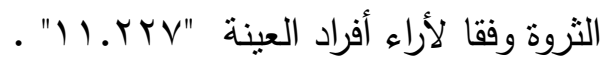
جدول ( ع ) الفروق في متوسط درجات أفراد العينة في التسويق الملبسي قبل وبعد الثثرة وفقا للحالة الأمنية

\begin{tabular}{|c|c|c|c|c|c|c|}
\hline الدلالة & قتيمة & درجات & العينة & الانحراف & الحسابي & الحالة الأمنية \\
\hline دال عند •... & \multirow{2}{*}{$r . . v$} & \multirow{2}{*}{1.9} & \multirow{2}{*}{11.} & 1.201 & $9.01 r$ & قبل الثورة \\
\hline لصالح قبل الثورة & & & &. $.90 \mathrm{~V}$ & $7 \ldots v$ & بعد الثورة \\
\hline
\end{tabular}




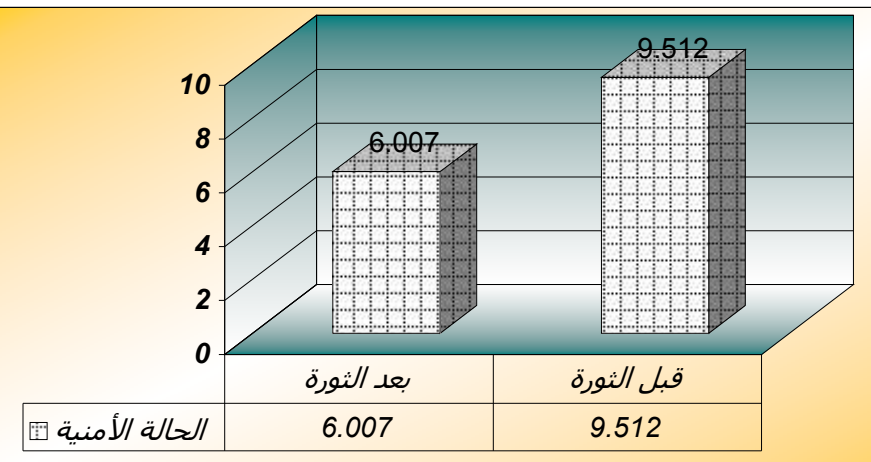

شكل r r ) يوضح الفروق في متوسط درجات أفراد العينة في التسويق الملبسي قبل وبعد الثورة وفقا للحالة الأمنية

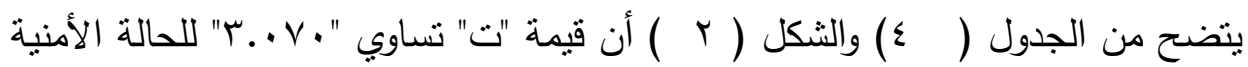

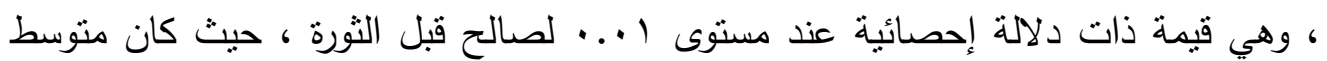

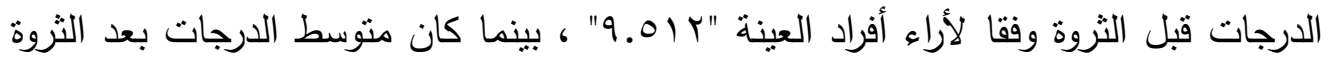

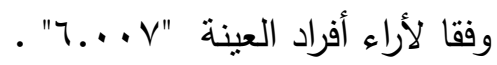
جدول ( ) الفروق في منوسط درجات أفراد العينة في النسويق الملبسي قبل وبعد الثورة وفقا لنقص البنزين والسولار العرات

\begin{tabular}{|c|c|c|c|c|c|c|}
\hline الدلالة & قيمة & الحرية & العينة & الالمعراف & المتوسط الحسبي & نقص البنزين والسولاز \\
\hline \multirow{2}{*}{ 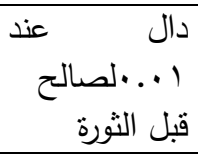 } & \multirow{2}{*}{7.111} & \multirow{2}{*}{1.9} & \multirow{2}{*}{11.} & 1.109 & $1 . .10 \mathrm{~V}$ & قبل الثورة \\
\hline & & & &.$v 00$ & $0.11 \leq$ & بعد الثورة \\
\hline
\end{tabular}

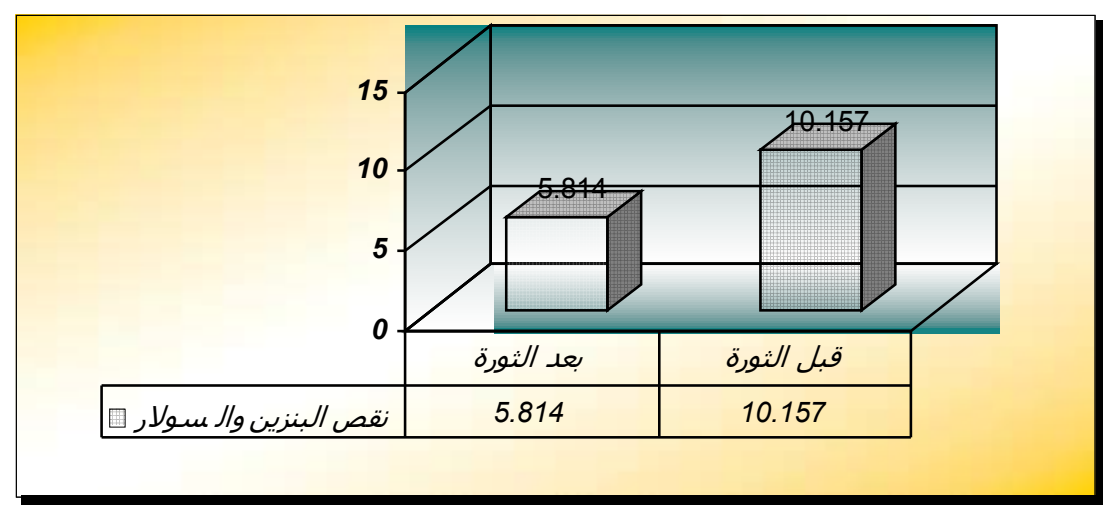

شكل ( r ) يوضح الفروق في منوسط درجات أفراد العينة في التسويق الملبسي قبل وبعد الثورة وفقا لنقص البنزين والسولار 


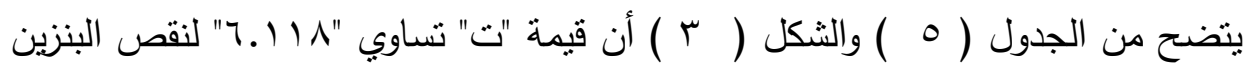

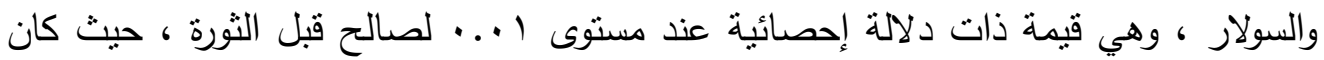

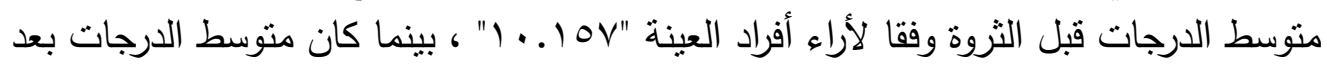

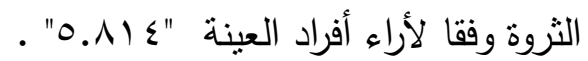
جدول ( T ) الفروق في منوسط درجات أفراد العينة في النسويق الملبسي قبل وبعد الثورة وفقا للمظاهرات والمطالب الفئوية

\begin{tabular}{|c|c|c|c|c|c|c|}
\hline الدلالة & قيمة & الحرية & العينة & الالمعراف & الحتوسطي & الفئوبة المظرات والمطالب \\
\hline \multirow{2}{*}{ لصال عند ال قبل الثثرة } & \multirow{2}{*}{$9 . \leqslant Y \leqslant$} & \multirow{2}{*}{1.9} & \multirow{2}{*}{11.} & $r . . V \wedge$ & $11.14 \leq$ & قبل الثورة \\
\hline & & & & 1.74 & $\varepsilon .9 .1$ & بعد الثورة \\
\hline
\end{tabular}

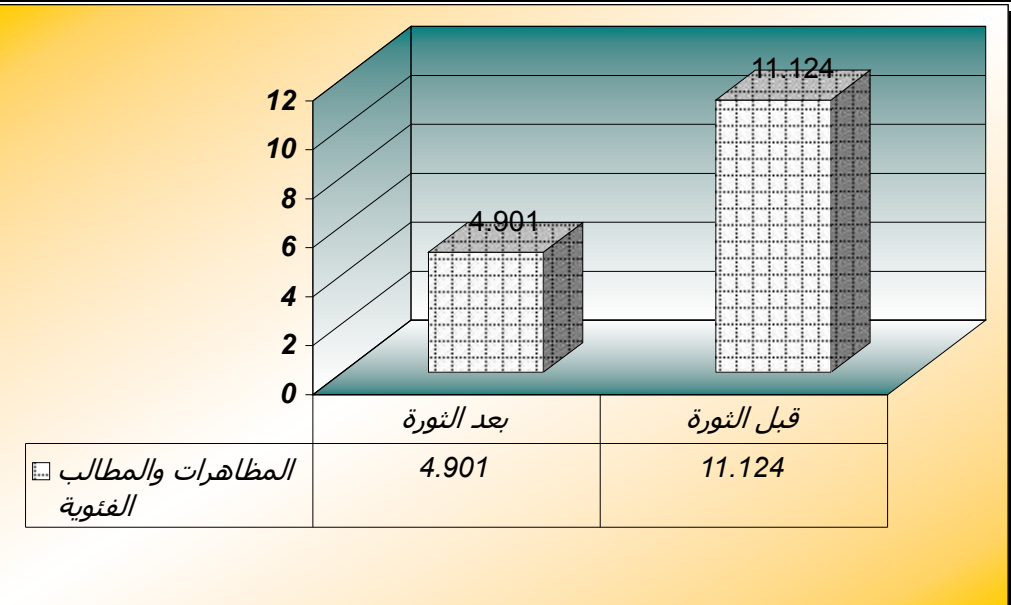

شكل يوضح الفروق في متوسط درجات أفراد العينة في التسويق الملبسي قبل وبعد الثورة وفقا للمظاهرات والمطالب الفئوية

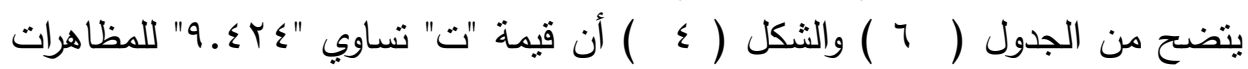

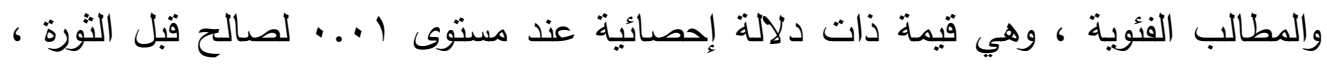

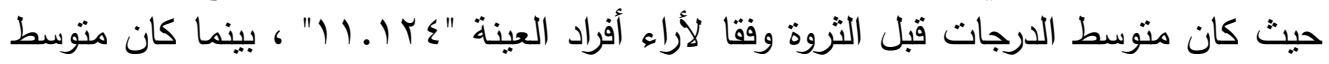

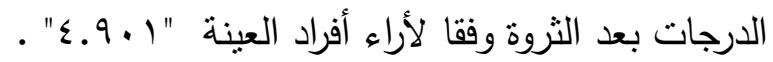
جدول ( V ) الفروق في متوسط درجات أفراد العينة في التسويق الملبسي قبل وبعد الثورة وفقا

\begin{tabular}{|c|c|c|c|c|c|c|}
\hline \\
\hline الدلالة & قايمة & الحرجية & العينة & الانحراف & الحسابي & العلاقات بين الدول \\
\hline \multirow{2}{*}{ لصالح قبل الثورة } & \multirow{2}{*}{5.119} & \multirow{2}{*}{1.9} & \multirow{2}{*}{11.} & $1.0 r 9$ & A.V $v \varepsilon$ & قبل الثورة \\
\hline & & & & $\therefore V \leqslant 1$ & 0.114 & بعد الثورة \\
\hline
\end{tabular}




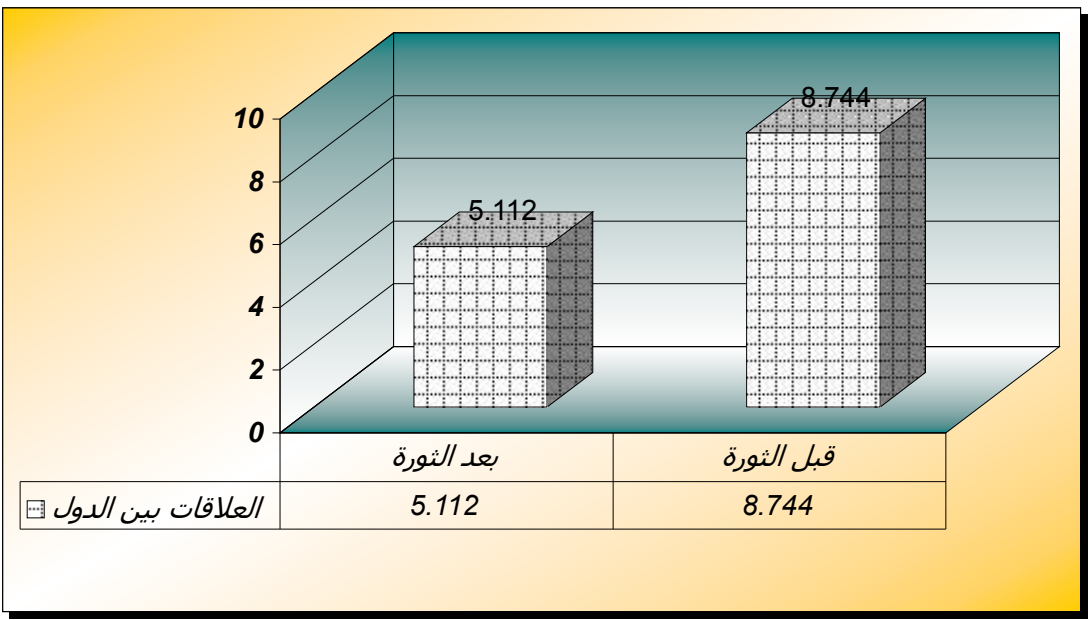

شكل ) يوضح الفروق في متوسط درجات أفراد العينة في التسويق الملبسي قبل وبعد الثورة وفقا للعلاقات بين الدول

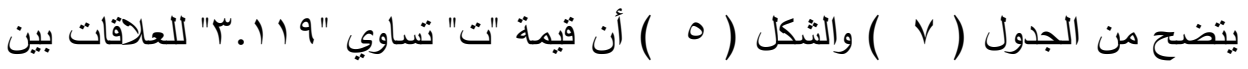

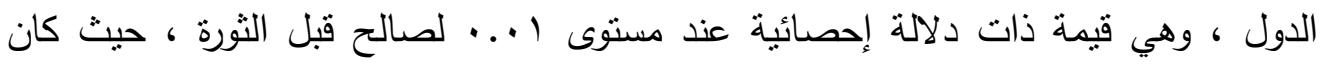

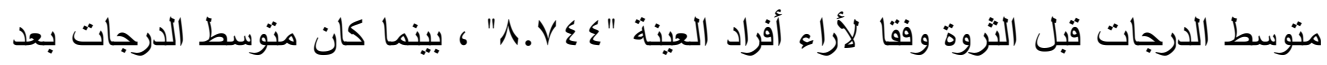

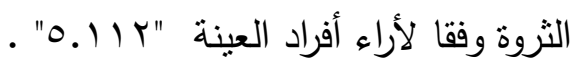
الفرض الثاني : الثروة

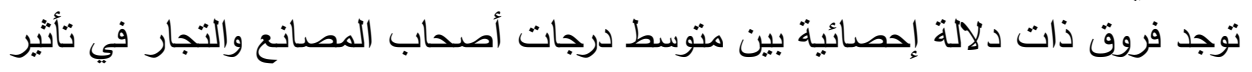

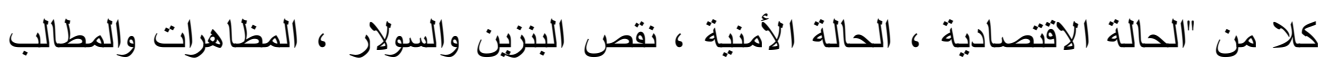

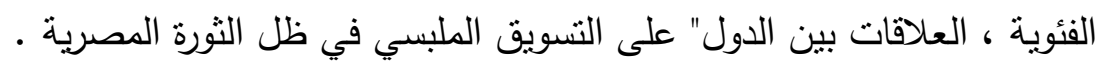

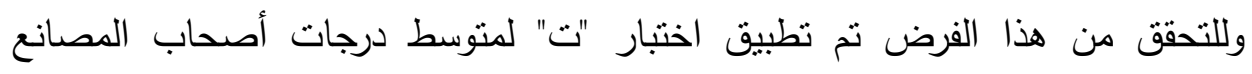

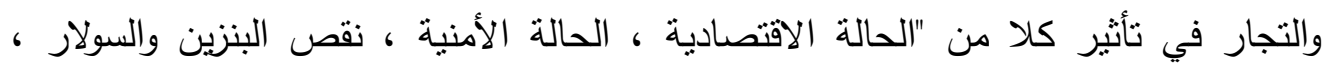

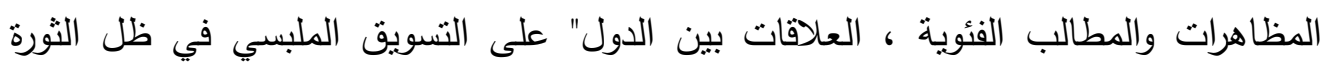

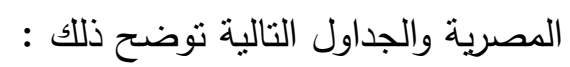
جدول ( ^ ) ) الفروق في منوسط درجات أصحاب المصانع والتجار في تأثير الحالة

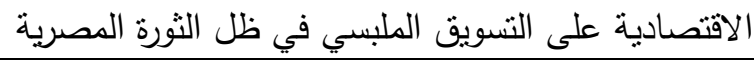

\begin{tabular}{|c|c|c|c|c|c|c|}
\hline الدلالة & قيمة & الحرية & العينة & الالحعراف & الحسابي & الحالة الاقتصادية \\
\hline \multirow{2}{*}{ لدال عند ألـاب } & \multirow[b]{2}{*}{ q.. rv } & \multirow[b]{2}{*}{1.1} & $r$. & 1.119 & $1 \Lambda . Y .7$ & أصحاب المصانع \\
\hline & & & 9. & 1.017 & $1 T . \wedge \wedge \Lambda$ & التجار \\
\hline
\end{tabular}




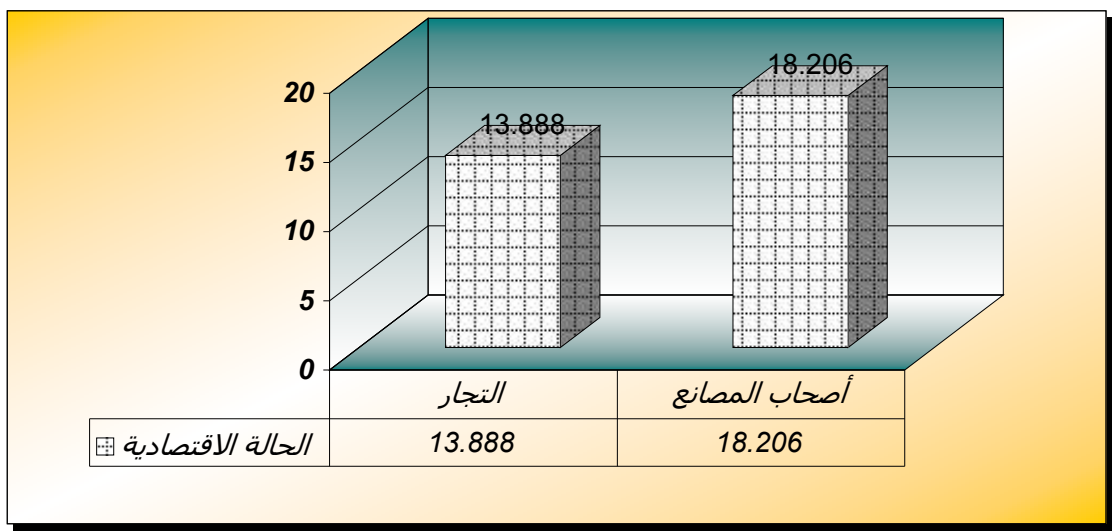

شكل ( 1 ) يوضح الفروق في متوسط درجات أصحاب المصانع والتجار في تأثير الحالة الاقتصادية على التسويق الملبسي في ظل الثورة المصرية

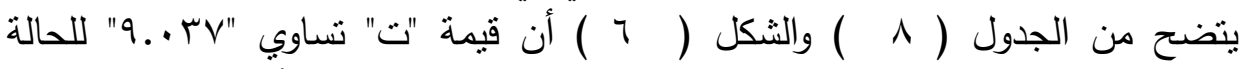

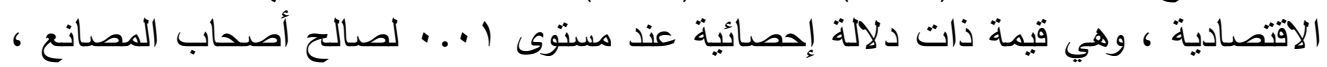

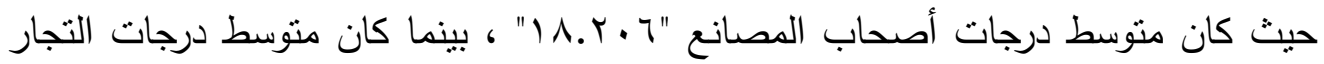

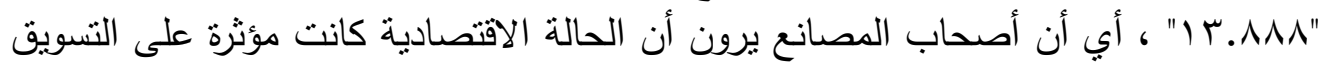

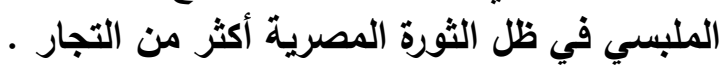

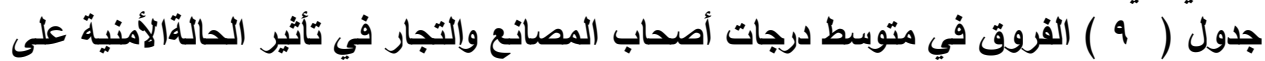
التسويق الملبسي في ظل الثورة المصرية النية في

\begin{tabular}{|c|c|c|c|c|c|c|}
\hline الدلالة الدالة & قيمة & تدرجا & العينة & الالمعراف & الحسابي & الحالة الأمنية \\
\hline \multirow{2}{*}{ دال عند ه... } & \multirow{2}{*}{ r...r } & \multirow{2}{*}{1.1} & $r$. & $r . . r$. & 1.190 & أصحاب المصانع \\
\hline & & & 9. & T. $9 \leqslant Y$ & $1 . .1 .0$ & التجار \\
\hline
\end{tabular}

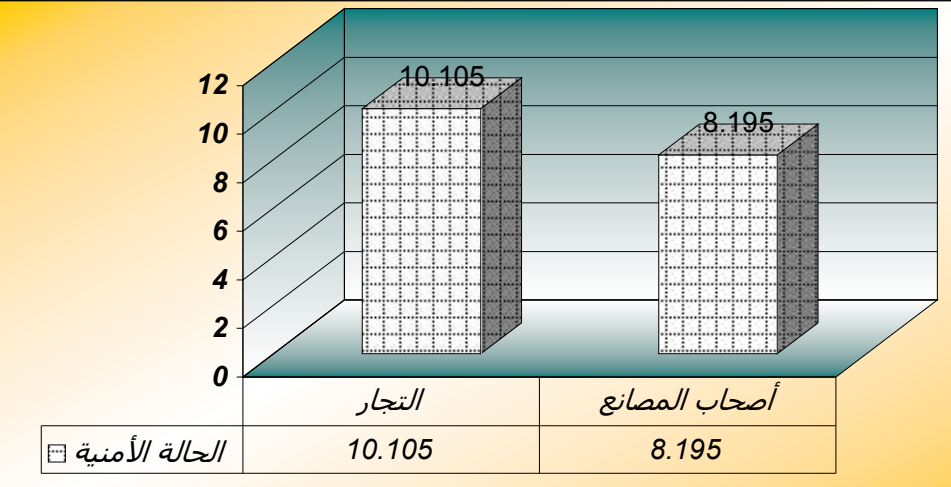

شكل ( ) يوضح الفروق في منوسط درجات أصحاب المصانع والتجار في ثأثثر الحالة الأمنية على التسويق الملبسي في ظل الثورة المصرية 


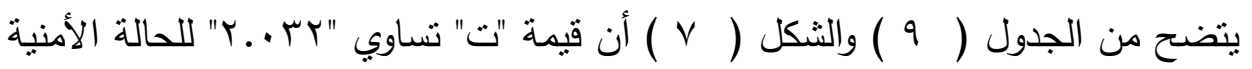

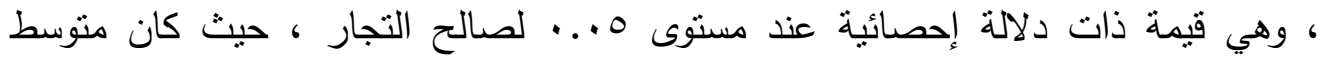

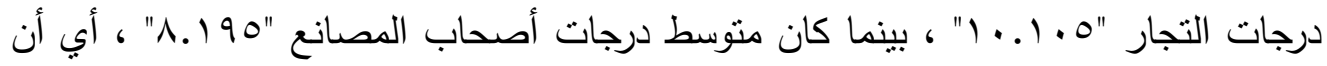

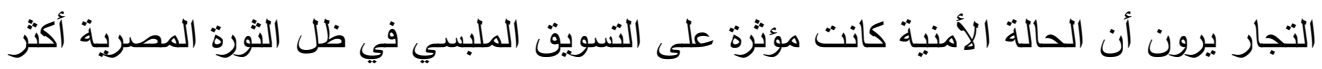

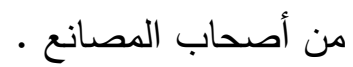
جدول ( () الفروق في متوسط درجات أصحاب المصانع والتجار في تأثير نقص البنزين والسولار على التسويق الملبسي في ظل الثنورة المصرية

\begin{tabular}{|c|c|c|c|c|c|c|}
\hline الدلالة & قيمة & درجات & العينة & الالنحراف & الحسابي & نقص البنزين والسولار \\
\hline \multirow{2}{*}{ غير دال. } & \multirow{2}{*}{1.01} & \multirow{2}{*}{1.1} & $r$. & 1.040 & $9.10 \mathrm{~V}$ & أصحاب المصانع \\
\hline & & & 9. & $1 . \vee \vee A$ & $\Lambda . \wedge V^{\prime}$ & التجار \\
\hline
\end{tabular}

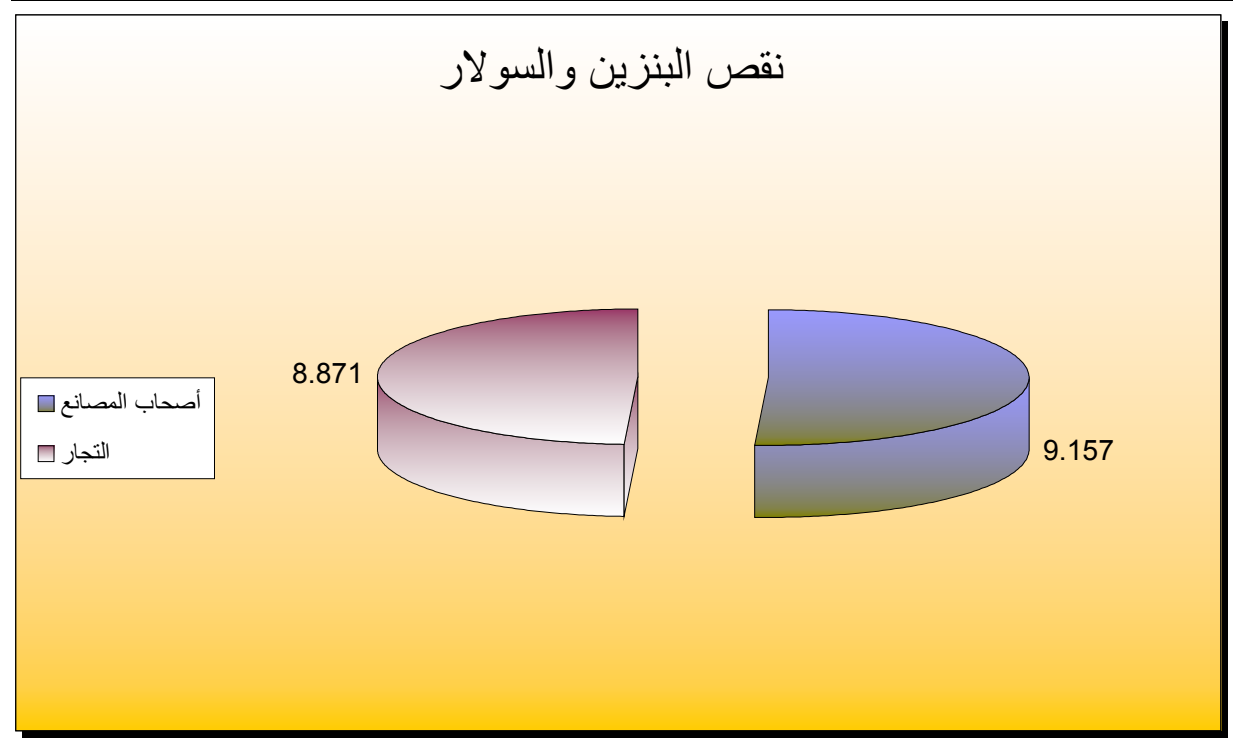

شكل (^ ) يوضح الفروق في منوسط درجات أصحاب المصانع والتجار في نأثير نقص البنزين

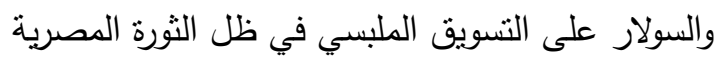

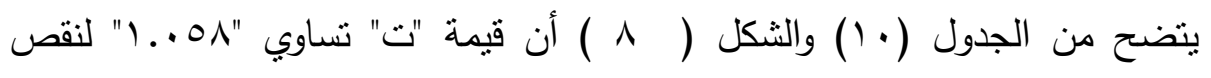

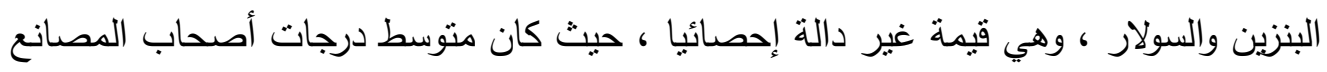

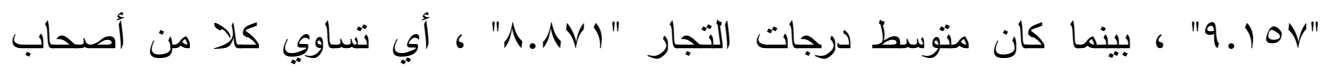
المصانع والتجار في أن نقص البنزين والسولار كان مؤثز على التسويق الملبسي في ظل 
جدول ( 11 ) الفروق في منوسط درجات أصحاب المصانع والتجار في تأثثر المظاهرات

والمطالب الفئوية على النسويق الملبسي في ظل الثورة الثران الدصرية

\begin{tabular}{|c|c|c|c|c|c|c|}
\hline الدلالة & ق تيمة & درجات & العينة & الالنحراف & الحسابي & المظاهرات والمطالب \\
\hline \multirow{2}{*}{ لدال عند التجار .. } & \multirow{2}{*}{ A. $\{07$} & \multirow{2}{*}{$1 \cdot 1$} & $r$. & $.9 r V$ & $T . \wedge \leq$. & أصحاب المصانع \\
\hline & & & 9. & I.TY & $11.0 \times 0$ & التجار \\
\hline
\end{tabular}

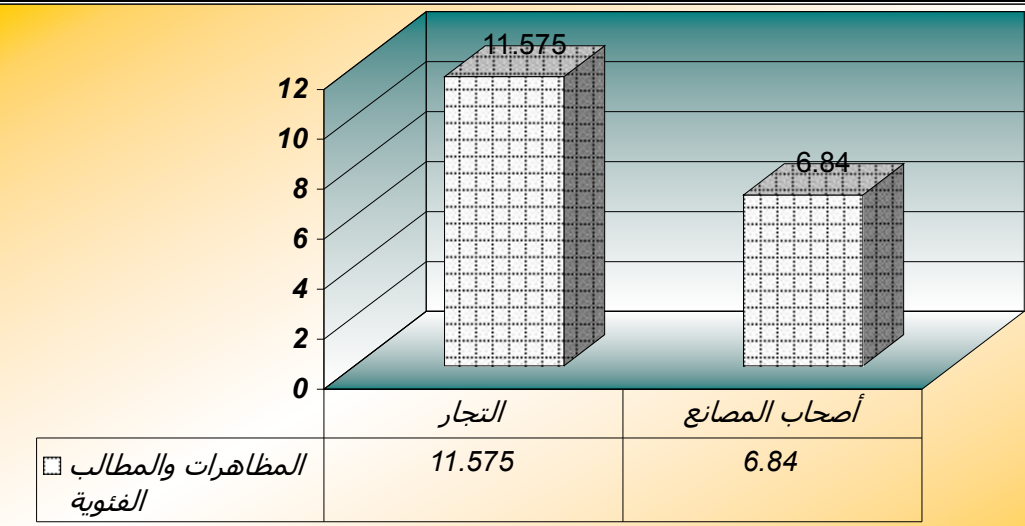

شكل (9 ) يوضح الفروق في متوسط درجات أصحاب المصانع والتجار في تأثير المظاهرات

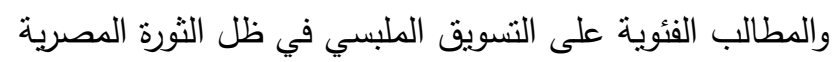

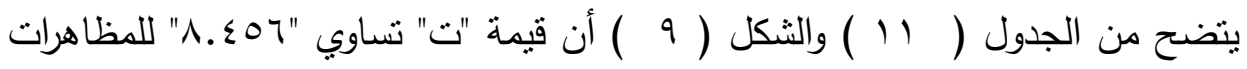

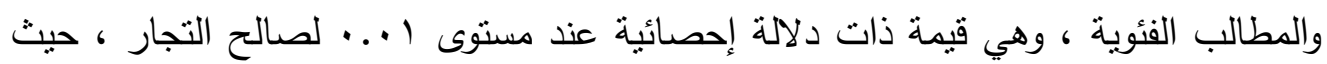

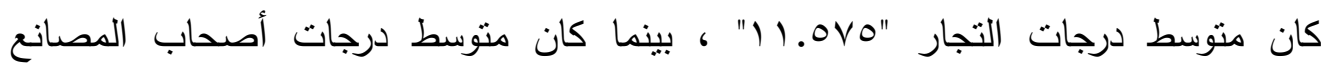

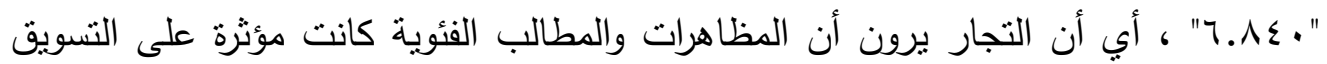

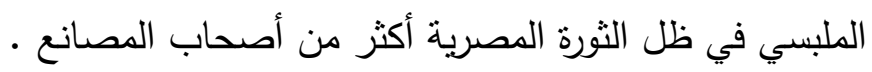

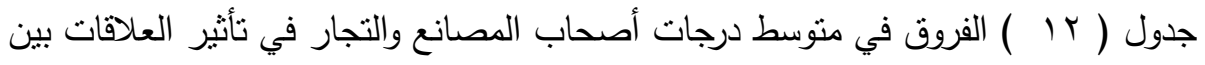

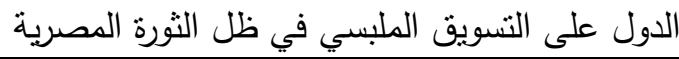

\begin{tabular}{|c|c|c|c|c|c|c|}
\hline الدلالة & قيمة & الحرجية & العينة & الانحراف & الحسابي & الدول العلات \\
\hline دال عند & \multirow[b]{2}{*}{$|T.| \leqslant \Lambda$} & \multirow[b]{2}{*}{$1 \cdot 1$} & r. & $1.21 \pi$ & 11.1 .1 & أصحاب المصانع \\
\hline أصحاب الصانع & & & 9. & .107 & $\varepsilon .9 \vee$. & التجار \\
\hline
\end{tabular}




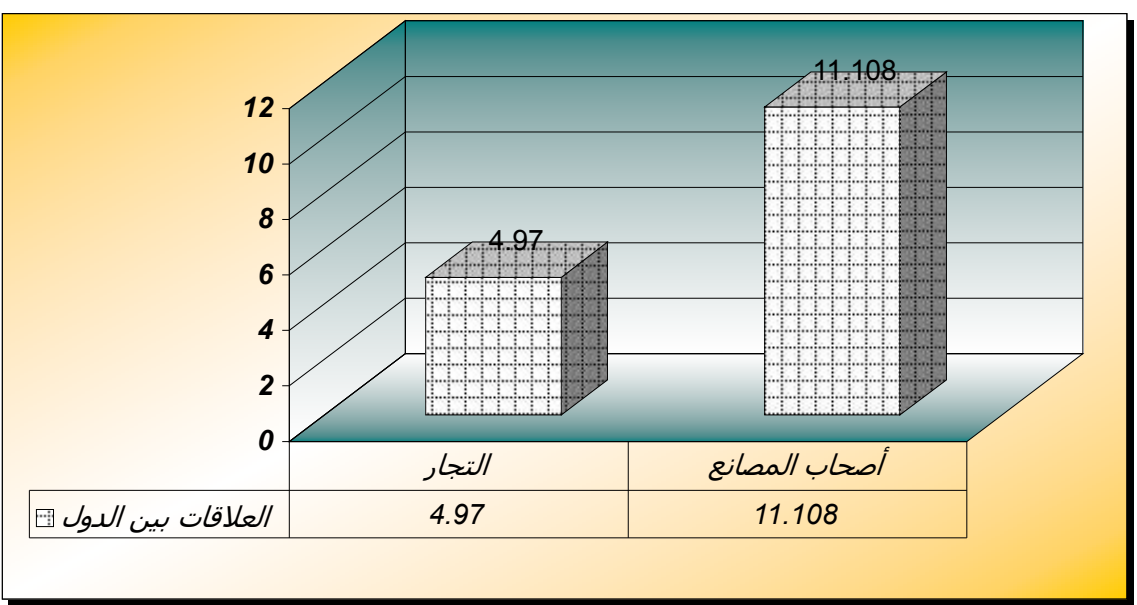

شكل · يوضح الفروق في متوسط درجات أصحاب المصانع والتجار في تأثير العلاقات

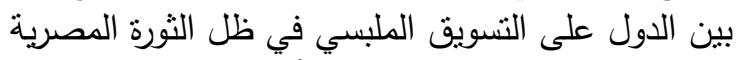

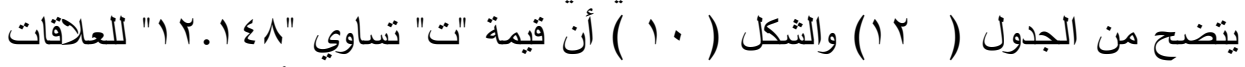

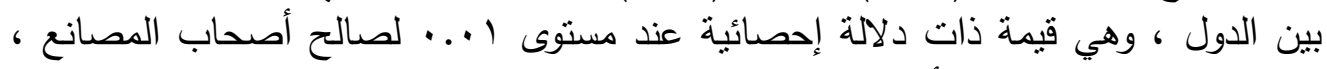

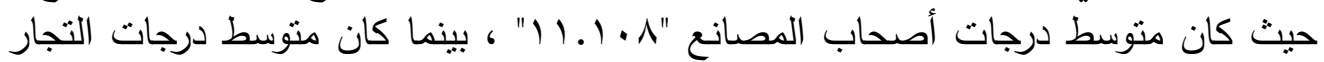

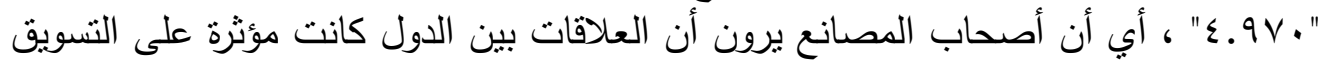

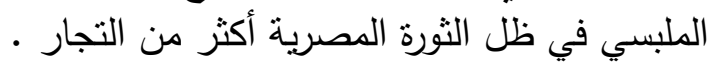

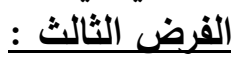

توجد علاقة ارتباطية بين كلا من "الحالة الاقتصادية ، الحالة الأمنية ، نقص البنزين

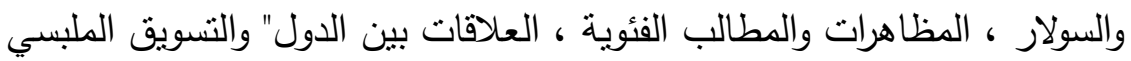

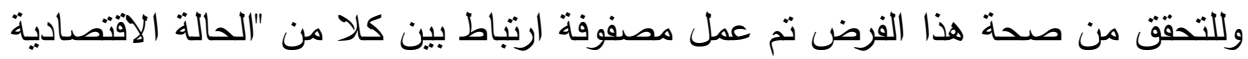

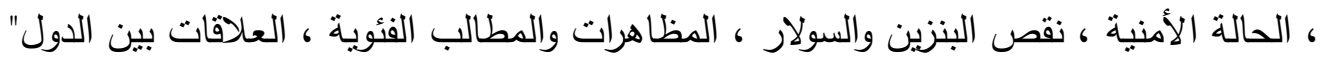

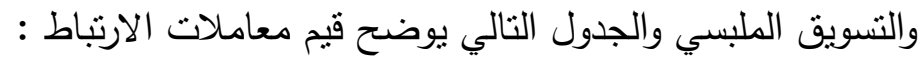

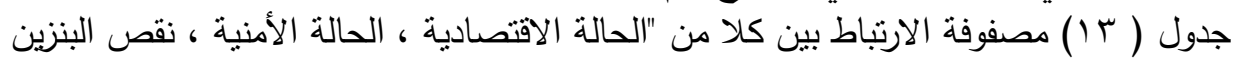

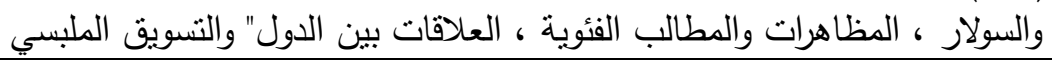

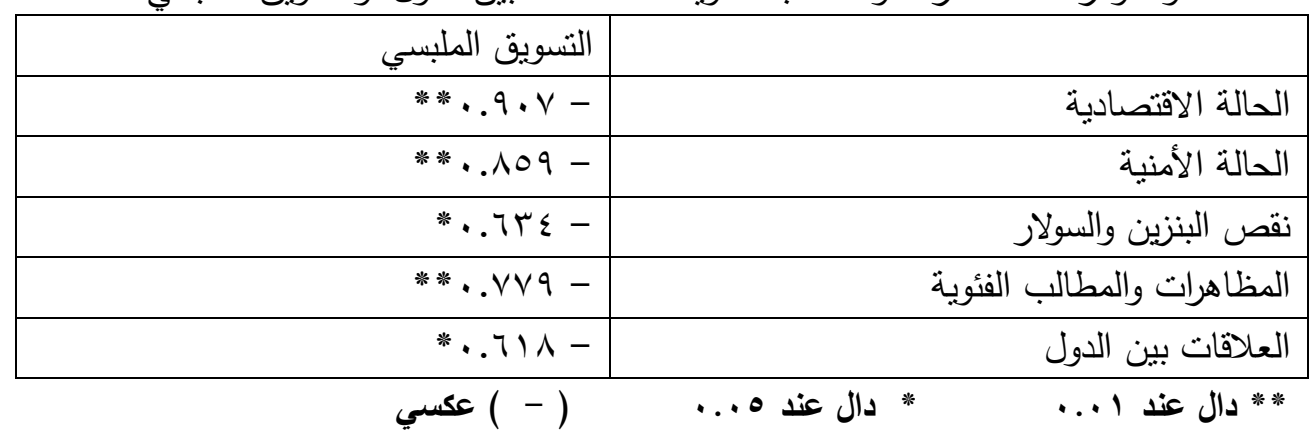

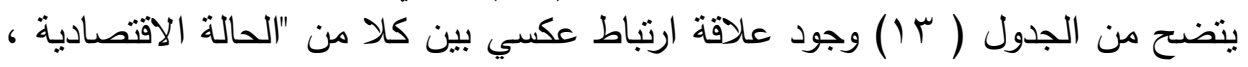

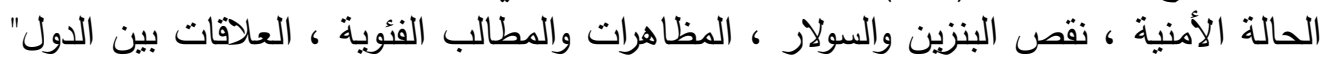




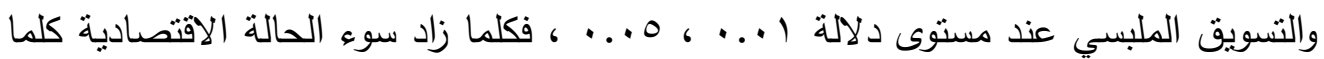

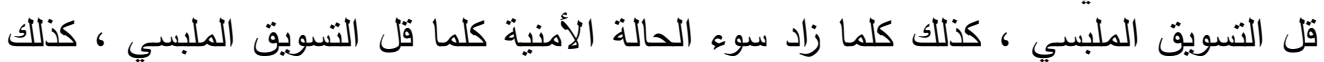

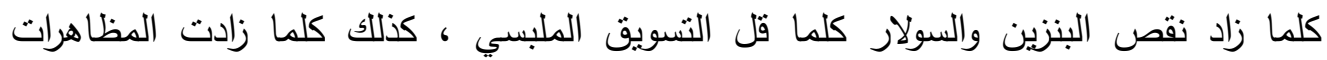
والمطالب الفئوية كلما قل التسويق الملبسي ، كذلك كلما زاد سوء العلاقات بين الدول كلما قل

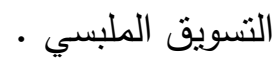
القرض الرابع :

توجد فروق ذات دلالة إحصائية بين منوسط درجات المحاور الخمس المؤثرة في

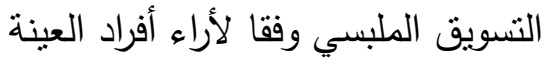

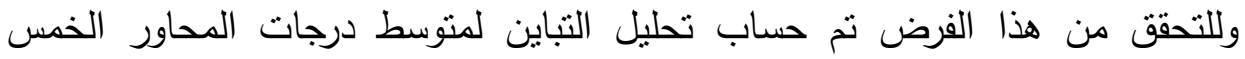

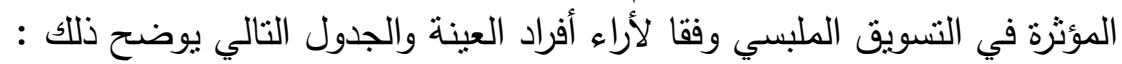

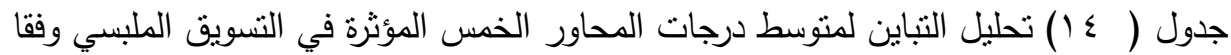

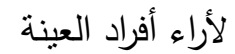

\begin{tabular}{|c|c|c|c|c|c|}
\hline الدلالة & قيمة (ف) & درجات الحرية & متوسط المربعات & مجموع المربعات & \\
\hline$\ldots+1$ & \multirow{2}{*}{$\varepsilon \varepsilon . \Gamma \ldots$} & $\varepsilon$ & $19 \leq \leqslant \ldots 7$ & VVVT... YO & بين المجموعات \\
\hline \multirow{2}{*}{ دال } & & $0 \leqslant 0$ & $\varepsilon r \Lambda . \Delta r Y$ & rTq10V.VVT & داخل المجموعات \\
\hline & & $0 \leqslant 9$ & & T1791V.V91 & المجموع \\
\hline
\end{tabular}

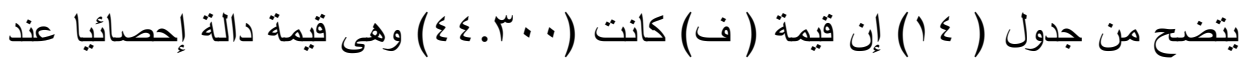

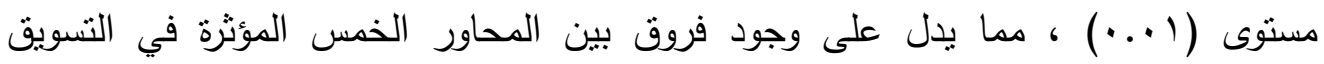

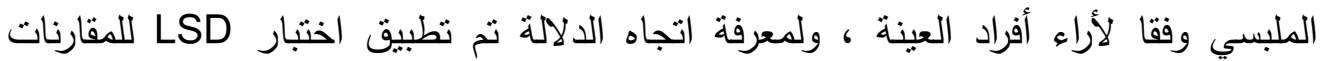
المتعددة والجدول التالي يوضح ذللك : جدول (10) إنتبار LSD للمقارنات المتعددة

\begin{tabular}{|c|c|c|c|c|c|}
\hline \multirow[t]{5}{*}{ 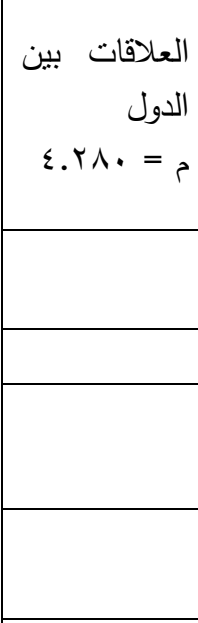 } & 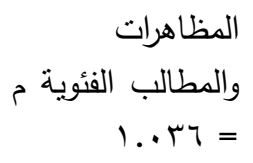 & 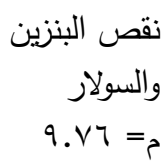 & 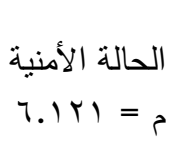 & الاقتصالة & \\
\hline & & & & - & الحالة الاقتصادية \\
\hline & & & - & **1Y.1. T & الحالة الأمنية \\
\hline & & - & $* * Y . T \leq T$ & ***人. $\leqslant \uparrow$. & والسولار البنزين \\
\hline & - & $* 1.479$ & $* *\{.910$ & $* * \vee .191$ & والدظالب الفئوية \\
\hline- & **4.У०५ & $* * 0 .\{\Lambda \mathrm{V}$ & $* 1 . \wedge \leqslant 1$ & $* * 1 r .9 \leq V$ & العلاقات بين الدول \\
\hline
\end{tabular}




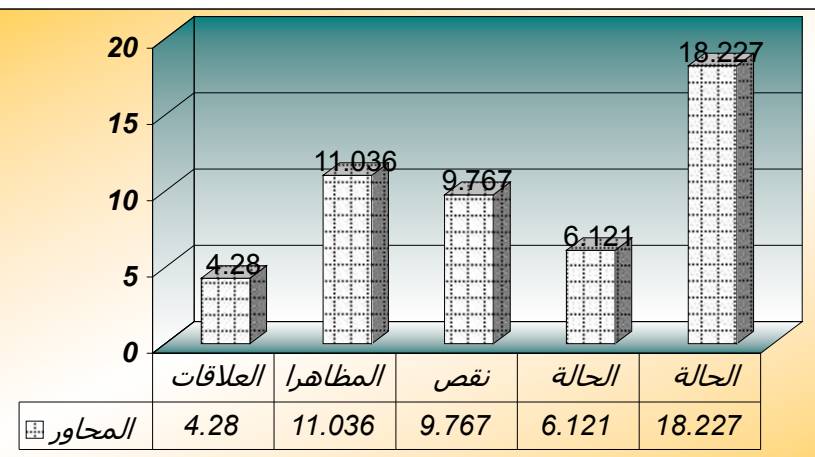

شكل ( (1) فروق درجات المحاور الخمس المؤثرة في التنسويق الملبسي وفقا لأراء أفراد العينة

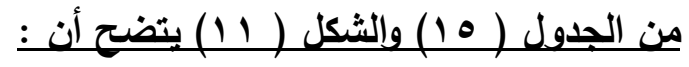
ا-وجود فروق دالة إحصائيا بين الحالة الاقتصادية وكلا من "المظاهرات والمطالب الفئوية ،

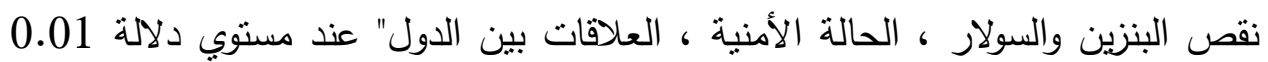

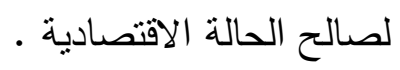

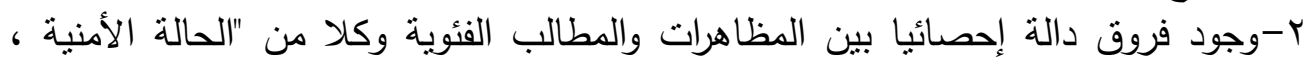

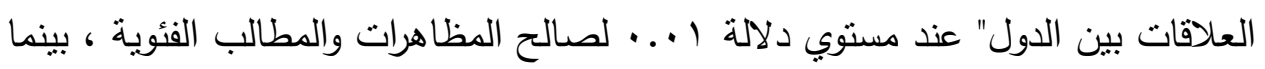

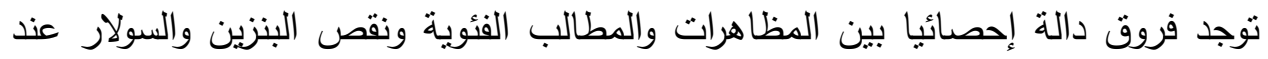

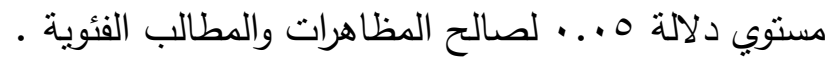

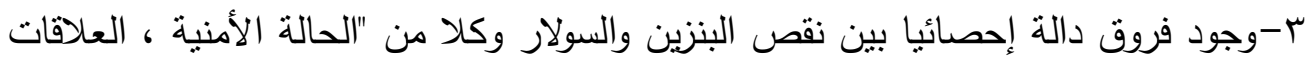

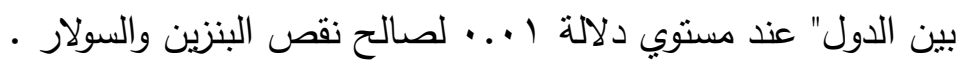

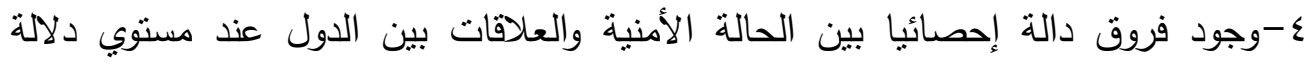

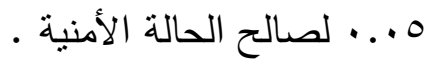

أو بصياغة أخري

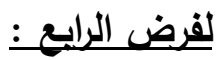

تختلف الأوزان النسبية لأكثر المحاور المؤثرة علي التسويق الملبسي وللتحقق من هذا

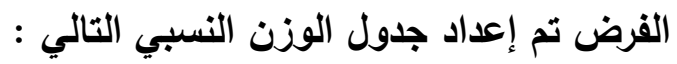
جدول ( 17 ) الوزن النسبي لأكثر المحاور المؤثرة علي التسويق الملبسي

\begin{tabular}{|c|c|c|c|}
\hline التزتيب & النسبة المئوية\%\% & الوزن النسبي & \\
\hline الأول & \%чт.r & Y19 & الحالة الاقتصادية \\
\hline 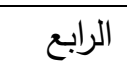 & $\% 17 . \varepsilon$ & irv & الحالة الأمنية \\
\hline الثالث & $\% \backslash \vee . \wedge$ & $1 \leqslant 1$ & نقص البنزين والسولار \\
\hline الثاني & $\% r \leqslant .0$ & $r \cdot \varepsilon$ & المظاهرات والمطالب الفئوية \\
\hline الخامس & $\% 10$ & Iro & العلاقات بين الدول \\
\hline & $\% 1 \ldots$ & אז & المجموع \\
\hline
\end{tabular}




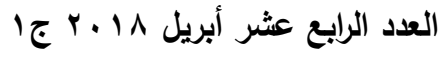

\section{المجلة العلمية لكلية التربية النوعية}

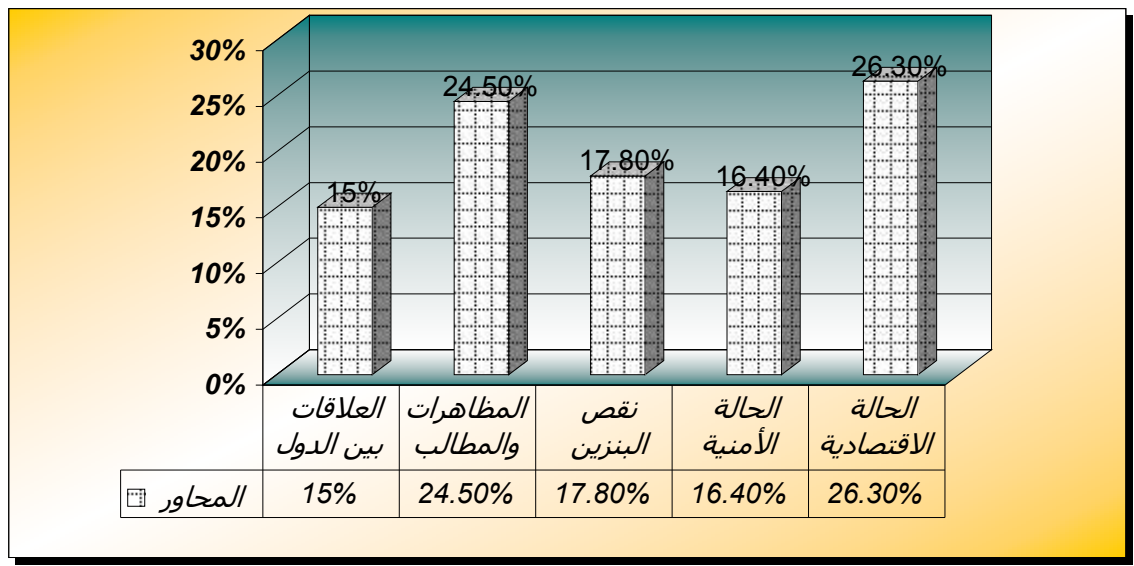

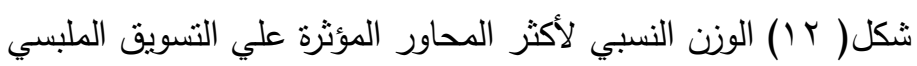

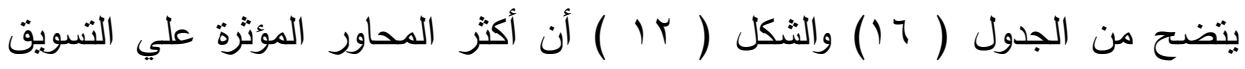

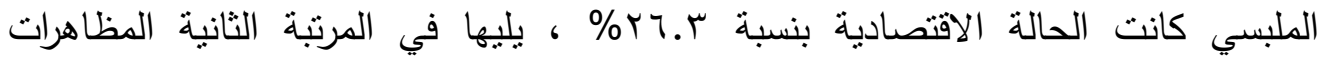

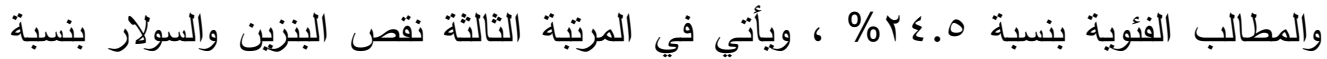

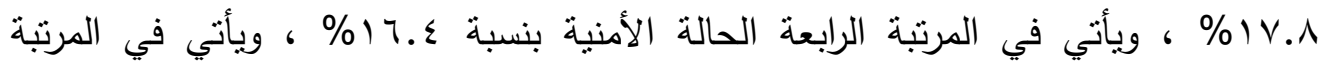

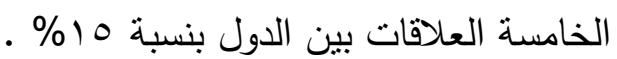

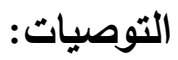

1-الاستفادة من نتائج البحث الحالي والعمل على النهوض بالحالة الاقتصادية والامنية والتي تعتبر من اكثر العوامل المؤثرة على التسويق الملبسي.

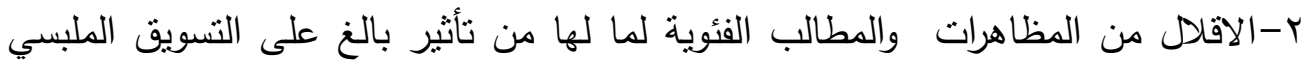
ومن ثم الاقتصاد المصري.

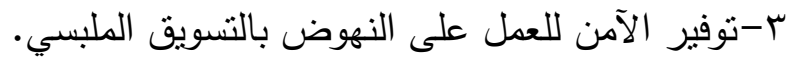


- ابراهيم امام محمد "تقييم سياسات تسويق الملابس الجاهزة" - رسالة ماجستير -كلية التجارة - جامعة

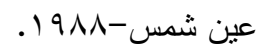

ץ-احسان دهش جلاب-هاشم فوزي العبادي "التسويق وفق منظور فلسفي ومعرفي معاصر"-مؤسسة الوراق

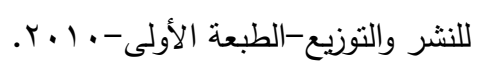

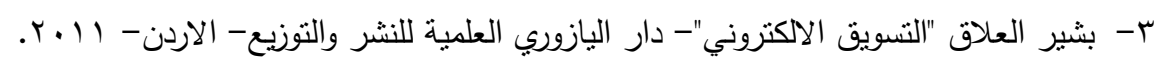
ع - جمال السيد الأحول "النسويق ودوره الاقتصادي في تصميم المنتجات المعدنية المنزلية" المؤتمر المصري لافي

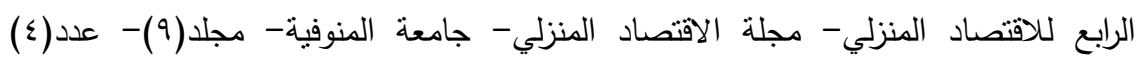

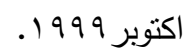

ه- حنان توفيق محمد والي "تأثير أساليب التعبئة والتغليف على رفع الكفاية التسويقية في مجال صناعة

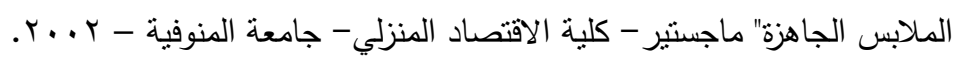
צ- سارة عبد الحميد الديب "أثز ثورة ب بناير على العلاقات المصرية الايرانية"مجلة الاستقلال - مركز

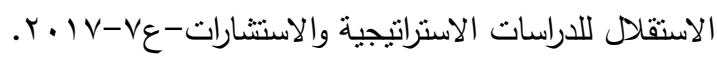

V- شفيق ابراهيم حداد ، نظام موسى اسويدان ، "أساسيات التسويق "، دار الحامد للنشرو التوزيع عمان

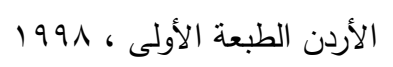

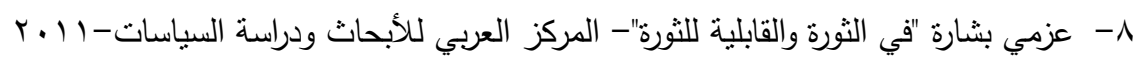
9- علاء امين الخواجة "اثز المتغيرات العالمية على استراتيجيات التسويق بقطاع الملابس الجاهزة دراسة

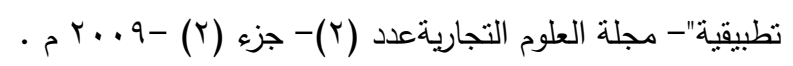

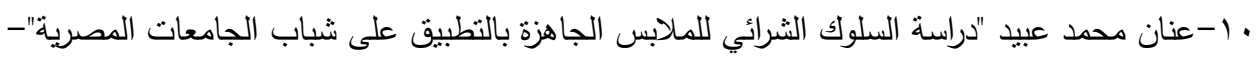

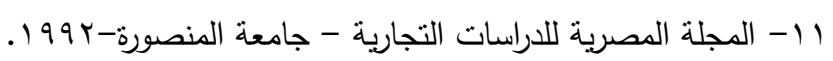

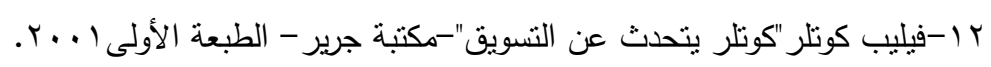
با -لطفية محمد بارك ، دالبا عبد الكريم قنديل" دراسة بعض المشاكل التسويقية للملابس الجاهزة النسائية

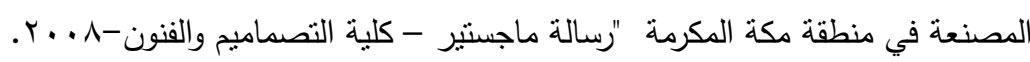

ع ا-ماجدة يحيى محمد" الاستفادة من الاتجاهات اللونية للموضة في الترويج لبعض الملابس الجاهزة "-

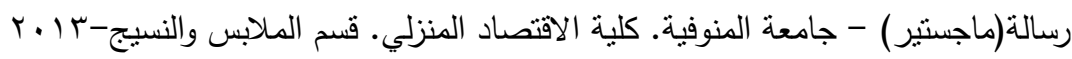

$$
10
$$

7 ا-ممدوح أحمد مبروك، مدحت محمد مرسي "مستقبل التسويق في مجال صناعة الملابس الجاهزة في مصر

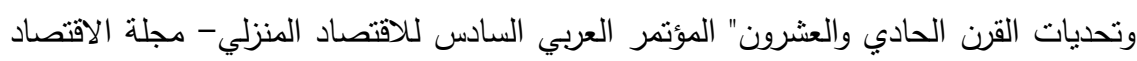

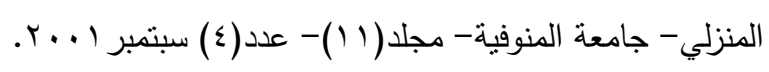

V ا-منال يوسف نجيب " علاقة التصميم بالتسويق لأقشة الملابس المطبوعة للأطفال"- رسالة دكتوراه ) -

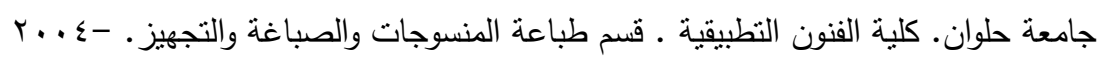


11-هاني حامد الضمور "تأثير عناصر المزيج النسويقي للملابس المنتجة محلياً على القرار الثرائي لربّات

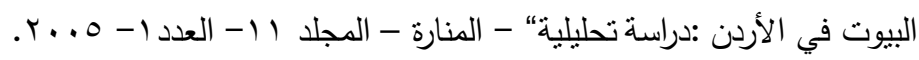

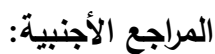

19- Malgorzata Koszewska "Understanding Consumer Behavior in the Sustainable Clothing Market: Model Development and Verification"-green fashionvolume1- Subramanian Senthilkannan Muthu Environmental Services Manager-Asia SGS Hong Kong Limited Hong Kong-2015.

20- Koszewska M "Social and eco-labelling of textile and clothing goods as means of communication and product differentiation". Fibres Text Eastern Europe 19:20-.r. 11

21- http//ar.wikipedia.com

22- Kotler .Philip and Keller "Marketing Management" 12th Ed. Prentice - Hall, 23- Englewood Cliffs, New Jersey, 2006.

24- David W.Cravens," Strategic Marketing "4th Ed. Irwin 1994. 